\title{
Hazard of Earthquake-Induced Lateral-Spread Ground Failure on the central California Coast Modeled from Earth-Science Map Data in a Geographic Information System
}

By RICHARD J. PIKE, RICHARD L. BERNKNOPF, JOHN C. TINSLEY III, and ROBERT K. MARK ${ }^{1}$

Susceptibility to lateral-spread ground-failure has been mapped by statistically combining geologic, hydrologic, and topographic information

\section{OPEN-FILE REPORT 94-662}

1994

This report is preliminary and has not been reviewed for conformity with U.S. Geological Survey editorial standards or with the North American Stratigraphic Code. Any use of trade, firm, or product names is for descriptive purposes only and does not imply endorsement by the U.S. Government 


\section{CONTENTS}

\author{
Abstract 3 \\ Geologic hazard and risk 4 \\ Objectives 5 \\ Soil liquefaction and lateral spreading 6 \\ The study area 10 \\ Method 13 \\ Multiple regression 13 \\ GIS implementation 14 \\ Selection of variables 17 \\ Observations 18 \\ Geologic map units 18 \\ Soil liquefaction and the \\ lateral-spreading hazard 18 \\ Age of geologic units $\mathbf{2 1}$
}

Sand content of deposits 22

Land-surface slope 22

Distance to surface water 25

Ground elevation 25

Data preparation 25

Estimating lateral-spread susceptibility 26

Threshold identification 27

The regression model 28

Statistical evaluation $\mathbf{3 1}$

Geologic evaluation and interpretation 32

Discussion 37

Recommendations for further work 40

Summary and conclusions $\mathbf{4 1}$

Acknowledgments 43

References 43

\section{PLATE}

1. Map showing susceptibility to lateral-spread ground failure in the Monterey Bay area, California [In pocket]

\section{TABLES}

1. Degrees of liquefaction susceptibility and their criteria for geologic units in the Monterey Bay area, central California 7

2. Characteristics of 36 geologic units mapped in the Monterey Bay area 15

3. Descriptions of 12 Holocene geologic units in the Monterey Bay area 16

4. Mean values of five independent variables for 50 geologic units in the Monterey Bay area 19

5. Twelve geologic units evaluated by multiple regression for susceptibility to lateral spreading 23

6. Performance of equation (1), regression for estimating susceptibility to lateral spreading $S_{R} 29$

7. Four-fold signatures of lateral-spread susceptibility for 12 geologic map units 33

8. Relative susceptibility to lateral spreading for 12 geologic units-ten ordinal rankings 35

\section{FIGURES}

1. Index map showing the six 7.5' USGS quadrangles in this study 8

2. Correlation of geologic map units in the Monterey study area 11

3. Outline of procedure for estimating susceptibility to lateral spreading $\mathbf{1 2}$

4. Field-based rankings of susceptibility to soil liquefaction and lateral spreading in the Monterey Bay area 20

5. Transformation of frequency distributions of independent variables - angle of ground slope 24

6. Histograms of computed susceptibility $S_{R}$ for nonzero cells and cells that hosted lateral spreads in the 1989 Loma Prieta earthquake 30

7. Comparison of $S_{R}$ with three other estimates of relative susceptibility to liquefaction or lateral spreading 36 


\title{
Hazard of Earthquake-Induced Lateral-Spread Ground Failure on the central California Coast Modeled from Earth-Science Map Data in a Geographic Information System
}

\author{
By \\ Richard J. Pike, Richard L. Bernknopf, John C. Tinsley III, \\ and Robert K. Mark
}

\begin{abstract}
Probabilistic maps, created on short notice and from available data, are needed to guide public policy and financial decisions in mitigating such geologic hazards as lateralspread ground-failure - one consequence of soil liquefaction induced by seismic shaking. Our numerical approach to mapping susceptibility to this hazard substitutes generalized geologic, hydrologic, and topographic information for the detailed geotechnical measures customarily used in site-specific work and microzonation assessments. The data, mostly compiled from existing maps for a $750-\mathrm{km}^{2}$ study area along the Monterey Bay coast of central California, were manipulated digitally in a geographic information system (GIS) at $100-\mathrm{m}$ resolution. We estimated susceptibility in a two-step procedure - first by threshold criteria and then by multiple-linear (probit) regression. The 49,564 1-ha parcels located in bedrock or in unconsolidated deposits too old $\left(>10,000\right.$ yrs BP) or steep $\left(>3^{\circ}\right)$ for lateral spreading were assigned susceptibility values of zero-which eliminated all but 12 of the study area's 36 geologic-map units. Relative susceptibility $S_{R}$, defined operationally as the chance that each of 25,508 remaining cells is located in one of two geologic units (Qyf, Qcf) judged by an expert as most likely to liquefy, is a function of age and sand content of the sedimentary deposits, horizontal distance to nearest surface water, and ground slope:

$$
S_{R}=4.8 \% \text { sand }-0.56 \ln \text { distance }-0.95 \log \text { age }-0.28 \ln \text { slope. }
$$
\end{abstract}

The regression, dominated by sand content and then age, is statistically significant (at the $1 \%$ level), internally consistent, and explains $76 \%$ of the variance. The resulting model of susceptibility is bimodal; most $S_{R}$ values are either very high or low. The digital map makes sense geologically in that the highest $S_{R}$ values commonly coincide with the most susceptible unit, late-Holocene flood-plain deposits (Qyf; mean $S_{R}=0.98$ \pm 0.03 ), and most of the 363 cells for which lateral spreading was observed in the 1989 Loma Prieta $M_{w} 6.9$ earthquake (mean $S_{R}=0.80 \pm 0.35$ ). The order of the 12 units in decreasing susceptibility $S_{R}$ is beach, younger flood plain, channel fill, young dunes, artificial fill, mixed alluvium, thin levee and overbank, basin deposits, alluvial fan, older dunes, older flood plain, and colluvium. This ranking agrees in general with other evaluations. Geologic units susceptible to lateral spreading are not uniformly so; the most hazardous sites lie closest to the Salinas and Pajaro Rivers and Monterey Bay. The model is conservative in that most high- $S_{R}$ cells hosted no failure in 1989 and the hazard is overestimated for beach sand. Geotechnical measures and data on depth-toground water would improve the model. The method devised here, and with appropriate caution a rather similar model, may be used to map the lateral-spreading hazard in areas of analogous geology and seismic risk in California. Suitably adapted, the model should also apply to ground settlement and other consequences of liquefaction. 


\section{GEOLOGIC HAZARD AND RISK}

Earthquakes, floods, landslides, volcanic eruptions, and other geologic hazards have serious economic and social consequences. These effects range from disruption of commerce to exhaustion of funds for insurance reimbursement (Berz, 1994). In determining geologic hazards and controlling or reducing their effects, it has become customary to assess risk-the danger posed to the general public. Because a risk-free existence is neither a realistic expectation nor an attainable goal, "zero threshold" concepts of risk that arise from political pressure can lead to prohibitively costly programs and needless disruption of society (Ross, 1990). The pragmatic approach is to determine various degrees of risk and then decide, for a given hazard scenario or need to mitigate, on acceptable levels of risk (Bernknopf and Soller, 1994). Such cost-effective estimates for specific geologic hazards can be used to make the landuse decisions on which to formulate policy for managing the Nation's resource-base and maintaining public safety (Bernknopf and others, 1988; Emmi and Horton, 1991; Molnia, 1994).

Because the effects of geologic processes are inherently spatial, estimates of risk from geologic hazards need to be determined over broad areas. This spatial, or regional, imperative in risk assessment has two major consequences. First, because geologic hazards in the United States transcend state boundaries, hazard mitigation has become a responsibility of publicly funded earth-science at the national level (National Research Council, 1993; Molnia, 1994). Second, recent experience with earthquakes in California has shown that effective strategies for mitigation depend on outlining potentially hazardous areas, as exemplified in this report, at least as much as they do locating the sources of the damaging processes themselves (Holzer, 1994).

Spatial estimates of risk and outlines of hazardous areas are best communicated in the form of maps (Youd, 1991; Borcherdt and others, 1991; Bernknopf, Brookshire, and others, 1993; Berz, 1994). The mapping can be implemented in various ways, depending partly on the hazard (see, for example, Kavazanjian and others, 1985; Youd and D.M. Perkins, 1987). If risk maps are required for large areas or on short notice for a specific area, however, the appraisal of geologic hazard through traditional (field) survey and site-specific engineering analysis (microzonation) may be too costly and take too much time. Under these constraints, computer-based methods in the office or laboratory may be used to create risk maps quickly and economically by combining available, coarse-scale, information with minimal added data from detailed field work (Brabb, 1987; Mark, 1992). The rapid compilation of such maps on a regional basis makes them useful for public policy and financial decisionmaking. The approach we have developed in mapping susceptibility to one type of seismically induced hazard is of this latter, rapid-response, variety.

In this report we estimate the varied susceptibility of a coastal area of central California to lateral spreading, a particularly damaging type of ground failure that results from soil liquefaction during a strong earthquake (National Research Council, 1985). The mapping of this hazard to the built environment was recently reviewed by Youd (1991) from the geotechnical perspective. The approach taken here is geologic and regional (Dupré and Tinsley, 1980; Juang and Elton, 1991; Ishihara and Yasuda, 1991, p. 710-713) rather than geotechnical and site specific (Seed and others, 1983; Hwang and Lee, 1991; Ishihawa, 1991, p. 712-721). Our method deliberately trades fine-scale detail, a high certainty, high cost, lengthy time, and low coverage for speed, reduced certainty, ease of compilation, broad coverage, and economy. After identifying nonsusceptible areas from threshold criteria, we combined geologic, hydrologic, and topographic map information mathematically (using a discrete-choice regression model) to estimate the susceptibility to lateral spreading. Both the input data and the results are manipulated in digital-map form, using a geographic information system (GIS) and a ground resolution (unit cell) of $100 \mathrm{~m}$ (1 hectare).

The nomenclature employed in evaluating soil liquefaction and its damaging consequences can cause confusion. Here we distinguish three quantities that have been mapped in previous 
studies of lateral spreading and its attendant risk (modified after Power and others, 1992):

Susceptibility - inherent vulnerability of soils to liquefaction/ lateral spreading; a measure of the relative likelihood that a geologic unit would undergo liquefaction/ ground failure during intense seismic shaking. We define this term more explicitly in the discussion of our model.

Opportunity - a function of the seismicity of an area and the frequency of occurrence of earthquake ground motions capable of causing liquefaction/ lateral spreading of susceptible materials.

Probability - an estimate of the absolute likelihood of occurrence, obtained by combining information on liquefaction/lateral spreading susceptibility with that on opportunity.

Evaluations of risk from a natural process or event are most useful when they are expressed quantitatively, as a continuous variable (Youd and D.M. Perkins, 1987; Burmaster and Lehr, 1991). (This presumes such numbers do not conceal critical information needed to evaluate a specific problem or locale.) Estimates of lateral-spread susceptibility and the resulting microzoned maps commonly are categorical, iow-mediumhigh, evaluations (Table 1; Youd and others, 1973; Chang and others, 1992; Matsuoka and others, 1993). Although indicative of the hazard and useful for a general appraisal, such qualitative estimates are difficult to translate into actual dollars-at-risk and other quantities that are needed to guide financial decisions for hazard mitigation and public policy (Bernknopf and Soller, 1994). This report introduces a numerical approach to evaluating lateral-spread susceptibility that is more amenable to follow-on work in risk assessment. The resulting estimates are not absolute (i.e., functional), or deterministic, values but rather are stochastic, or statements of probability. A statistical approach to mapping lateral-spread susceptibility, opportunity, and severity is not new and has been implemented ir, other ways (e.g., Kavazanjian and others, 1985; Youd and D.M. Perkins, 1987; Turner and Youd, 1987; Juang and Elton, 1991).

\section{OBJECTIVES}

The study had three immediate goals. The first was to devise, under some severe constraints, a statistical model that ranks susceptibility to lateral spreading in the Monterey Bay area of central California. We were charged with accomplishing this ranking rapidly, at low cost, over a comparatively large area, with no new field study, and independently of the usual geotechnical datainstead, using off-the-shelf map information as surrogates or proxies for those data. The map derived from such numerical rankings (Plate 1) had to discriminate among potentially failed sites that are smaller than the Quaternary geologic-map units distinguished according to degree of hazard by Dupré and Tinsley (1980) and Tinsley and others (in press). Our second goal was to "calibrate", or test, the resulting statistical model and map from occurrences of lateral spreading observed in a recent earthquake in the study area. The final objective was to have devised a pragmatic approach, and perhaps even a specific model, for mapping lateral-spread susceptibility that-appropriately adapted-could be applied to other, geologically analogous, areas in California and elsewhere.

We emphasize that we did not intend to model lateral spreading per se, which lies beyond the scope of the assignment, nor did we directly equate this process or the damage resulting from it with any suite of empirical characteristics. Rather, we adopted an operational, working definition of the effects of lateral spreading in terms of comparative judgments made by experts in the mapping of sedimentary deposits susceptible to spreading (e.g., Dupré and Tinsley, 1980). Based on geologic observation and interpretation, the historical record of soil liquefaction during large earthquakes, and prior geotechnical analysis in the field, these judgments include a ranking of the relative susceptibility of geologic-map units to lateral spreading and the identification of physical factors that contribute to the varied likelihood of lateral spreading.

Longer-term objectives are not addressed in this report. Our statistical mapping of 
lateral-spreading susceptibility is an interim step toward the eventual goal of quantitative digital maps that can be used to more directly evaluate land-use and other policy decisions. The next logical step is a map showing opportunity, the probability of lateral spreading in a specific earthquake, which would depend upon a mapped model of seismic shaking (Bernknopf, Mark, and others, 1993). Mapping the resulting damage to areas of human occupation would require additional calculations, involving land-use information that includes data on the built environmentthe type and age of structures (e.g., Shah and others, 1991; King and Kiremidjian, 1994). Mapped estimates of dollars-at-risk would require yet another calculation, using demographic information from the census and property valuation from real estate transactions (e.g., Bernknopf and others, 1994). Such derivative maps, which depend on specialized data not routinely available within the earth sciences, probably are best created in cooperation with appropriate state and local agencies, academia, and the private sector (e.g., King and Kiremidjian, 1994).

\section{SOIL LIQUEFACTION AND LATERAL SPREADING}

Liquefaction is a physical process wherein granular soil can temporarily undergo loss of inter-particle effective stresses, due to rise in excess pore-water pressure. As a result, the soil loses its resistance to shear-and consequently its ability to support weight. Defined (Youd, 1973) as "the transformation of a granular material from a solid state into a liquefied state as a consequence of increased pore-water pressure", the process occurs only in loose to moderately dense, non-cohesive, watersaturated deposits-chiefly medium and finegrained sands and silts - that are subjected to strong and persistent seismic shaking (Youd and Hoose, 1977). Liquefaction can give rise to various types of damaging ground failure (National Research Council, 1985).

Lateral spreading is a type of ground failure wherein shear strength of the soil falls below the free-field downslope shear stresses. A common consequence of lateral spreading is the differential lateral displacement of blocks of terrain above a liquefied layer, creating networks of ground fissures. The process occurs in young geologic deposits in seismically active areas worldwide (Ishihara and others, 1990; Youd, 1991; Ishihara and others, 1992; Tokimatsu and others, 1991; Matsuoka and others, 1993). In the United States, lateral spreading is a known hazard in much of lowland California (e.g., Bennett, 1990; Stewart and others, 1994) and coastal Alaska (Hansen, 1965), as well as being recognizedthrough evidence from historical earthquakes-as a potential hazard in coastal South Carolina (Martin and Clough, 1990; Elton and Hadj-Hamou, 1990) and the upper Mississippi embayment (Fuller, 1912, p. 47-58; Obermeier and others, 1990; Chang and others, 1992).

Lateral spreading is not the sole causative agent of major damage to the built environment, although it is the only one addressed here. Other consequences of soil liquefaction, such as slumping of stream banks due to inertial forces and vertical ground settlement may be equally severe (e.g., Youd and Hoose, 1978). Liquefaction can cause differential settlement of overlying deposits, can bring about bearing capacity failures and the flotation of positively buoyant structures (storage tanks, conduits, culverts, drainage channels), and can erupt at the surface as sandboils (sandblows) (Fuller, 1912, p. 79-83; Obermeier, 1989; Bennett, 1990; Ishihara and others, 1992). Settlements accounted for much ground failure in the 1906 and 1989 California earthquakes. The Marina District in San Francisco, in fact, owed most of its damage in 1989 to settlement; lateral spreading per se was absent there (Bennett, 1990).

Many factors (e.g., earthquake magnitude and distance from a seismic source) influence the occurrence of liquefaction and the types of ground deformation that result. These factors are both dynamic, transient effects related to the characteristics of a particular earthquake, and site-specific, the character of the land surface and the physical properties of its underlying materials National Research Council, 1985). 
Table 1

Degrees of Liquefaction Susceptibility and Their Criteria for Geologic Units in the Monterey Bay area, central California*

VERY HIGH: Historical evidence of extensive liquefaction-induced ground failure in the 1906 earthquake, and high susceptibilities based on engineering tests. Sediments are very likely to liquefy (and fail) in even a moderate earthquake. Mainly restricted to younger flood-plain deposits plus some basin deposits, beach sand, and dune sand near Moss Landing.

HIGH: $\quad$ Engineering tests, shallow water tables, and local presence of free faces indicate high susceptibilities despite no reports of historical evidence for liquefaction. Sediments are likely to liquefy in a nearby major earthquake. Includes some basin and younger flood-plain deposits, plus most undifferentiated alluvial deposits and abandoned channel-fill. Most dune sand and some beach sand are also included.

MODERATE: Historic evidence of liquefaction absent, although high susceptibilities calculated in engineering tests. May liquefy in a nearby major earthquake. Includes older flood-plain, most basin, and colluvium deposits, most undifferentiated alluvial deposits, and some late Pleistocene-Holocene eolian deposits.

LOW: Unlikely to liquefy, even in a nearby major earthquake. Materials include almost all Pleistocene deposits, plus Holocene deposits where the water table is at least $10 \mathrm{~m}$ below the surface (e.g., most alluvial fan deposits).

VERY LOW: Sediments are highly unlikely to liquefy, even in a nearby major earthquake. They include all pre-Quaternary deposits.

\footnotetext{
* modified after Dupré and Tinsley (1980). The combination of two susceptibility categories, e.g., MODERATE-LOW (Table 5, Figure 4), indicates that an area is not uniformly susceptible. Although the same geologic unit may underlie the entire area, such factors as depth to the water table may vary and the susceptibility might be LOW in one part and MODERATE in another.
} 




Figure 1. Topographic map showing the six 7.5' USGS quadrangles (in left-toright pairs, from north to south) that comprise the study area:

Watsonville West and East, Moss Landing and Prunedale, and Marina and Salinas. Each quadrangle is about 11 by $14 \mathrm{~km}$. Contour interval 200 feet $(61 \mathrm{~m})$ with supplementary contours at 100 foot $(30 \mathrm{~m})$ intervals. 
Surface oscillation, a dynamic factor in lateral spreading, can induce failure far from stream banks and other unconfined slopes (see below), especially in extensive plains of liquefiable materials. Resulting open fissures that range in width from $0.5 \mathrm{~m}$ to a few raters are not exceptional, thousands of meters removed from a steep declivity. Surface oscillation may be particularly important in the meizoseismal region of very strong (say, $M_{w}$ $>7.5$ ) earthquakes. Fuller (1912, p. 47-58) describes and Wesnousky and Leffler (1992) illustrate such effects in the central region most affected by the 1811-12 New Madrid earthquakes. Obermeier (written commun., 1994) has observed similar evidence in the Wabash Valley of Indiana-Illinois, where liquefaction was induced by an earthquake about 6000 years ago.

The severity and spatial distribution of such dynamic effects of an earthquake as surface oscillation cannot be determined for an area a priori. Accordingly, site-specific conditions must be relied upon to map the susceptibility to lateral spreading and other consequences of liquefaction. Previous work has identified several geologic, hydrologic, and topographic factors. They include sedimentological and engineering properties (for recent reviews, see Youd and D.M. Perkins, 1987, and Youd, 1991). Given sufficiently severe and prolonged seismic shaking, the intrinsic conditions of a site that may give rise to lateral spreading number at least seven: in general terms, these factors are age and type of sedimentary deposit, depth to ground water, proximity to an unconfined slope (free face), terrain slope, near-surface stratigraphy of the deposit, and character of the underlying sedimentary basin.

1. Young fluvial sediments that are poorly consolidated and uncemented are more likely to liquefy, and then spread, than old deposits that tend to have sustained diagenetic changes. Late Holocene materials are the most susceptible (Tinsley and others, 1985; Youd and D.M. Perkins, 1987). In California, sediments older than Holocene ( $>10,000$ yrs. BP) have a low to very low potential for liquefaction (Dupré and Tinsley, 1980; Youd and J.B. Perkins, 1987), although elsewhere late Pleistocene and older materials are known to have liquefied severely in strong earthquakes (Obermeier, 1989; Obermeier and others, 1990; Ishihara and others, 1990).

2. The character of a sedimentary deposit, to the extent that it may influence liquefaction susceptibility, is perhaps best expressed by its density state (or soil state)density under a given effective stress. Density state reflects the initial (depositional) fabric as well as changes accumulating through diagenesis plus static and dynamic loading imposed by burial and seismic shaking. Distribution of particle size (sorting) and grainto-grain arrangement (packing) contribute importantly to density state. Uniform loose sands and silty sands are most likely to liquefy; gravelly sand and deposits containing sufficient clay to make the material cohesive are less likely to fail (Seed and Idriss, 1982; Tinsley and others, 1985; Tinsley and Dupré, 1992). Most deposits containing more than $15 \%$ clay are too cohesive to fail by liquefaction (Seed and Idriss, 1982), although sensitive clays (those that have acquired a very low shear strength) can also liquefy extensively.

3. Only water-saturated materials, including deposits not saturated initially (e.g., loess, Ishihara and others, 1990), can liquefy. Depth to the ground-water table correlates somewhat inversely with engineering calculations of the critical cyclic-stress ratio required to cause liquefaction in susceptible materials. Liquefaction is unlikely to occur in deposits where the water table lies much below $10 \mathrm{~m}$. For this reason, thin exposed deposits are unlikely to liquefy. Conversely, susceptibility is very high where ground water is less than 3 $m$ from the surface (Youd and Perkins, 1978), although this general relation in part reflects youthfulness of the uppermost saturated unit and, thus, supports condition 1 (above).

4. Potential for the damaging horizontal displacements that characterize lateral spreading is increased by the presence of a nearby cut slope or free face such as the bank of a stream channel, irrigation canal, or openconduit storm drain (Youd, 1973), or other boundary conditions wherein the liquefied materials are not laterally confined (e.g., 
Ishihara and others, 1990)-and thus subjected to increased downslope shear stresses. Such conditions are, however, not mandatory for the occurrence of lateral spreading.

5. The historical record specific to coastal lowlands of California shows that a lateral spread is most likely to occur on very gentle, essentially level, slopes that range between $0.3^{\circ}$ and $3.0^{\circ}$ (Tinsley and others, 1985; Youd and D.M. Perkins, 1987). However, although most failures on steeper slopes tend to be labelled "debris flows" or "mud flows" (e.g., Ishihara and others, 1990), in fact they_ represent the same mechanical phenomena of lateral spreading: a state of imbalance between the mobilized shear strength and downslope shear stress. Steep natural slopes may not fail with the commonly regarded appearance of "lateral spreads" because steep slopes are less laterally extensive. They commonly are formed on colluvium or other densely packed and nonliquefiable materials and may not be water saturated (R. Kayen, written commun., 1994).

6. Near-surface stratigraphy can be locally critical. Thick beds, for example, are more likely to intersect the ground-water table and thus are more apt to liquefy than thin deposits. Additionally, a thin, lowpermeability layer, or cap, commonly overlies the sands that liquefy in an earthquake (Obermeier and others, 1990; Ishihara and others, 1993). The slope of the interface between this cap and the underlying sand is specifically influential: lateral-spread movements can be greatly enhanced in the dip direction of the interface (S. Obermeier, written commun., 1994).

7. Enhanced ground shaking, owing to the shape of an underlying sedimentary basin and the stratigraphy of its fill, can contribute significantly to soil liquefaction and its effects. In the Loma Prieta earthquake, for example, thick cohesive soils underlying many locales are thought to have amplified relatively modest levels of bedrock shaking such that peak acceleration in the susceptible soils at the surface far exceeded values predicted by models (Seed and others, 1991).

These factors and other data, in different combinations, have been used previously to compile maps of susceptibility, potential, and severity for soil liquefaction and its various effects. The resulting maps include those by Chang and others (1992), Dupré and Tinsley (1980), Elton and others, 1990), Juang and Elton (1991), Matsuoka and others (1993), Tinsley and others (1985), Youd and D.M. Perkins (1978, 1987), and Youd and others (1973, 1978). Much of this work was reviewed by and summarized by Turner and Youd (1987) and Youd (1991).

\section{THE STUDY AREA}

Low-lying alluvial plains bordering Monterey Bay in central California have a history of seismically induced liquefaction, much of it leading to lateral spreading, that includes major effects from the $M_{w} 7.81906$ San Francisco earthquake (Lawson and others, 1908; Youd and Hoose, 1978, p. 13-22). The most severe ground failures in 1906 were concentrated in late Holocene sediments along the Pajaro and Salinas Rivers and in similar fluvial deposits underlying beach and dune deposits near and between the mouths of these rivers (Figures 1 and 2; Plate 1). Dupré and Tinsley (1980) mapped the geology of eight 1:24,000-scale (7.5') quadrangles in this area. In ranking 36 geologic units (Table 2) according to their liquefaction potential (Table 1), they incorporated information on sites that failed by lateral spreading and other consequences of liquefaction in the 1906 earthquake. Recurrence of spreading in this area in the 1989 Loma Prieta event (Seed and others, 1991; Dupré and Tinsley, in press) provided sufficient data to test a probabilistic model for mapping the hazard from this process. We chose six of the quadrangles mapped by Dupré and Tinsley (1980) to develop such a model (Figure 1).

The $750-\mathrm{km}^{2}$ study area is topographically and geologically heterogeneous. Pre-Quaternary igneous, sedimentary, and metamorphic rocks of the Santa Cruz Mountains in the northeast (up to $575 \mathrm{~m}$ ) account for $10 \%$ of the area. Bounded by the NW-trending San Andreas Fault Zone, the remaining $90 \%$ to the south and southwest consists of flat- to moderate-relief terrain between sea level and about $200 \mathrm{~m}$. The topography is developed on a wide variety of 
Figure 2

Correlation of 35 Geologic Map Units in the Monterey Study Area

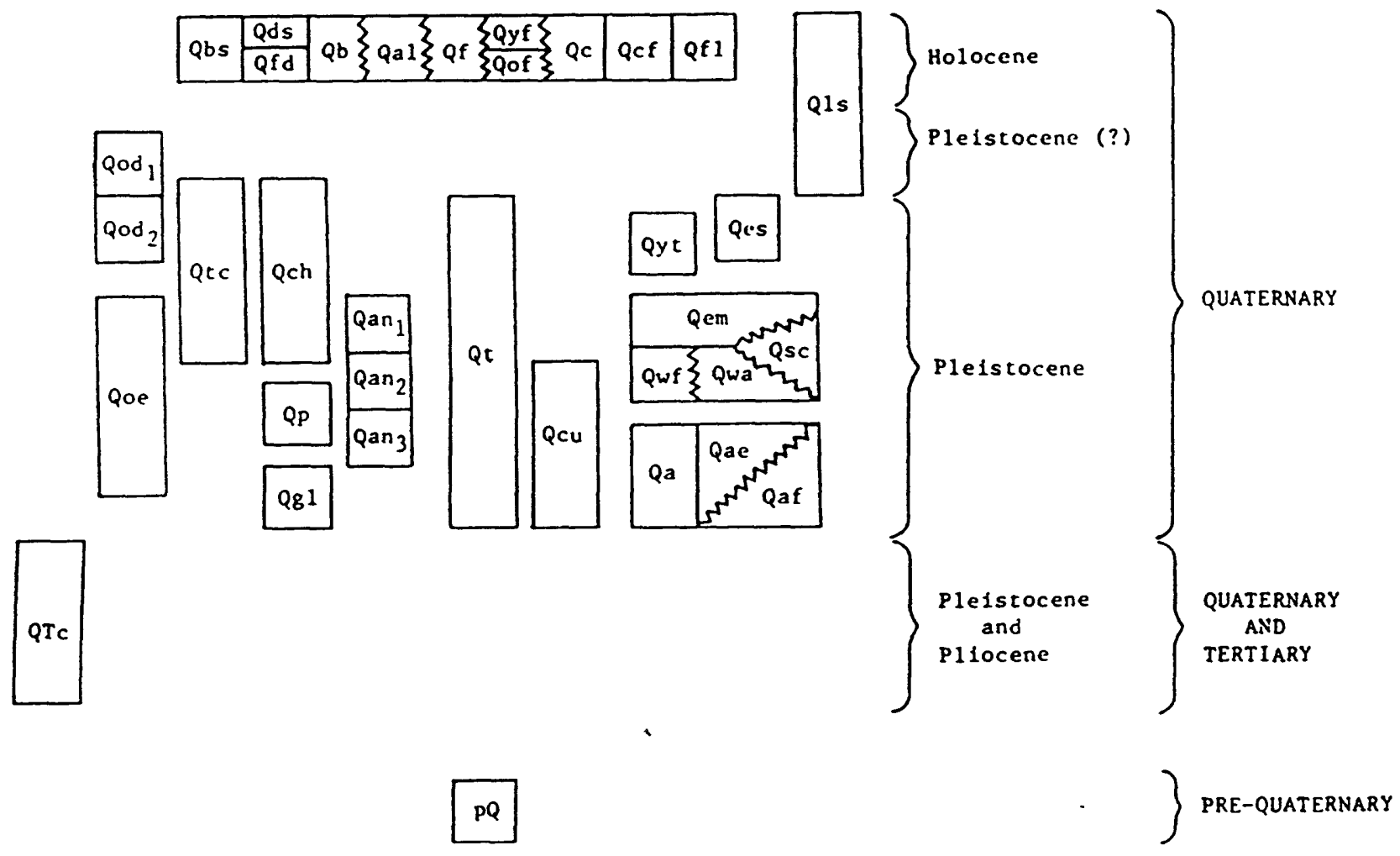

After Dupré and Tinsley (1980). See Table 2 for brief descriptions of all units, and Table 3 for detailed decriptions of 12 Holocene units. Qyf includes unit Qyfa 
Figure 3

Outline of Procedure for Estimating Susceptibility to Lateral Spreading, $S_{R}$

I. Prepare Information

A. Obtain or compute contributing data

B. Insert data into GIS, converting to raster where necessary

C. Examine data; transform where necessary<smiles>C=C</smiles>

II. Identify Nonsusceptible Areas

A. Define absolute susceptibility; choose criteria

B. Apply thresholding criteria to data

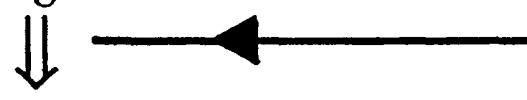

III. Devise Model for Relative Susceptibility

A. Define susceptibility as dependent variable

B. Choose independent variables

C. Compute relative susceptibility, $S_{R}$, by probit regression<smiles>C=CC=C</smiles>

IV. Generate Susceptibility Map

A. Divide $S_{R}$ into intervals; choose colors

B. Plot hardcopy<smiles>C=CC=C</smiles>

V. Evaluate Model

A. Descriptive and diagnostic statistics

B. Map patterns and relation to geology

C. 1989 Loma Prieta lateral-spread sites

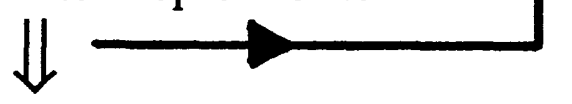

VI. Accept Results 
alluvial and eolian materials ranging in age from Pliocene to late Holocene (Dupré and Tinsley, 1980; Tinsley and Dupré, 1992). The 12 units most susceptible to lateral spreading are described in detail in Table 3. Older flood plain (Qof) is the most prevalent of the mapped deposits ( $12 \%$ of the area), followed by basin (overbank) deposits ( $Q b, 10 \%$ ), the Aromas sand $(\mathrm{Qa}, 8 \%)$, and older coastal dunes (5\%). The two most highly susceptible units (Table 2), younger flood-plain sediments (Qyf) and channel fill (Qcf), together occupy only $4 \%$. Although comparatively little of the study area is prone to lateral spreading, the locales most likely to fail in this manner coincide with sites of human occupancy or land use, particularly in and around the town of Watsonville (Figure 1).

\section{METHOD}

A multivariate statistical approach is essential for the rapid, broad-scale mapping of geologic hazard and risk because these phenomena are complex and the mapping criteria generalized (Bernknopf and others, 1988; Pike, 1988; Mark, 1992). In the absence of data on the residual shear strength and downslope shear stress, surrogates for these geotechnical measures-several characteristics of a sedimentary deposit and its physiographic setting - are required to predict susceptibility to lateral spreading and other consequences of soil liquefaction. Multiple criteria are especially important where the available data are incomplete, inaccurate, or qualitative (Juang and Elton, 1991). In such cases, a multivariable model can be a more reliable tool for prediction than the individual data used to build it. A composite model can also amplify hidden patterns and minimize unwanted statistical noise (Gauch, 1993).

To apply the multivariate approach we compiled digital maps for four of the general factors known to influence susceptibility to lateral spreading (compare, for the debris-flow hazard, Mark, 1992) and then combined the four maps (not shown) statistically. The result is a new map (Plate 1) showing numerical estimates of spreading susceptibility. This rapid, computer-based method replaces the traditional overlay technique, whereby maps showing different characteristics are compared manually on a light table and synthesized by drawing lines that best generalize the component maps (McHarg, 1969; Omernik, 1987). The transition from this technique to the computer synthesis of multiple maps in digital form has been a major recent development in the applied earth and environmental sciences (Robinson and Spieker, 1978; Burrough, 1986).

We defined susceptibility to lateral spreading (independent of a specific earthquake) as the intrinsic susceptibility of each 1-ha cell to this process, based on site factors that predispose a cell to spreading. Because many sites are so unlikely to fail that they can be excluded on the basis of threshold (absolute) criteria, we first identified such cells (using numerical data) and assigned them a susceptibility value of zero. To map the hazard for the remaining (non-zero) cells in the area, we then devised an operational definition of relative susceptibility $\left(S_{R}\right)$, based on a ranking of different geologic units by experts, and equated it statistically with a suite of properties that can be measured for each cell. The result of these two-stage calculations is a colored digital map on a $0-1$ scale (Plate 1). Figure 3 outlines the overall procedure.

Plate 1 is not the product of our initial calculations, but rather the result of an exploratory and heuristic process (Figure 3 ). We carried out many experiments before reaching the results presented here. Although we believe that Plate 1 is the optimal map given the data and analytic software currently available to us, several of the interim maps (not shown) created in the course of the study would also give acceptable estimates of susceptibility to lateral spreading (e.g., Bernknopf, Mark, and others, 1993).

\section{Multiple Regression}

For each 1-ha cell not assigned zero susceptibility from threshold criteria (described below), we modeled susceptibility by the multiple linear regression of experts' 
ranking (of relative susceptibility) on a suite of physical factors. Regression, wherein a linear statistical relation between two or more variables is used to predict or estimate one variable from the other(s), differs somewhat from correlation, which measures the association between variables. In multiple regression, values of $Y, a$ dependent (predicted) variable, are estimated statistically from a linear combination of two or more (i) independent (explanatory) variables $X$, in the basic (ordinary least squares, or OLS) form

$$
Y=B_{0}+B_{1} X_{1}+\ldots+B_{i} X_{i}
$$

where $B_{0-i}$ are unknown coefficients to be determined, by the method of least squares, from the available data for $Y$ and $X$. The goal of OLS is to account for the maximum variation in the dependent variable by the explanatory variables included in the model. For more information see Hoel (1962, pp. 172-179), or other introductory texts on statistics. Multiple linear regression is further explained, with increasing thoroughness, by Davis (1986, p. 469478), Dillon and Goldstein (1984, p. 209-301), and Draper and Smith (1981).

In OLS, both dependent and independent variables are continuous, ratio-scale, quantities. In the probit form of multiple regression that we required for determining the susceptibility to lateral spreading, the dependent quantity is a dichotomous (0-1), or dummy, variable. That is, the predicted quantity is available in only two values, 0 and 1. As formulated here a 1-ha parcel occurs as a discrete choice, either in a highly susceptible ("1") or in a less-susceptible ("0") sedimentary deposit, as judged by an expert. The probit model creates an unobservable index, a latent variable $I$, which is a linear function of the independent variables in the simplified form

$$
I=B_{0}+B_{1} X_{i} \text {. }
$$

The index I, which ranges from minus to plus infinity and is non-linearly related to the independent variables, is translated to a $0-1$ range by use of the cumulative normal distribution (White and others, 1990, p. 137). The probit model differs little from the more familiar logit, or logistic regression, model (Bernknopf and others, 1988; Mark, 1992); the choice between the two distributions usually is one of computational convenience. For further explanation of the calculations involved, see Gujarati (1988, p. 491-499). Equation coefficients are estimated iteratively. The probit algorithm used here converges rapidly, usually in four or five iterations (White and others, 1990, p. 137).

The calculations in this study were made in SHAZAM (White and others, 1990), a computer program used for econometric analysis. Because econometrics is built largely upon multiple regression, the technique is perhaps best developed in that field (e.g., Maddala, 1983; Gujarati, 1988). SHAZAM is not restricted to applications in econometrics, but can handle any numerical problem requiring statistics to determine relations among variables. The software can estimate many types of models and has many options, including the diagnostic statistics appropriate to each type of regression. Although the package has a programmed demonstration and a detailed user's manual (White and others, 1990), the explanation and significance of the various regression procedures and program outputs must be sought elsewhere. Perhaps the best reference is Gujarati's (1988) textbook, which is integrated with the computer handbook by White and Bui (1988).

\section{GIS Implementation}

The value of computer technology in mapping a wide variety of geologic hazards has been amply demonstrated (e.g. King and Kiremidjian, 1994; for examples in nearby San Mateo County see Brabb, 1987 and Mark, 1992). Our work on lateral spreading was made possible by a geographic information system (GIS)-a combination of computer hardware, software, and procedures for the input, manipulation, transformation, analysis, modeling, and output of spatially arrayed (map) information (Burrough, 1986; Cowan, 1988; Wentworth and others, 1991). The role of GIS in this study cannot be overestimated. The work reported here, which entailed the rapid creation and evaluation of model after model (and the resulting maps) from multiple large sets of data, would not exist otherwise. Most recently, applications of GIS to seismic 
Table 2

Characteristics of 36 Geologic Units in the Monterey Bay area, central California*

$\begin{array}{ccc}\text { GEOL. LIQUEF. } & \text { ABBREVIATED } & \text { SEDMMENTARY } \\ \text { UNIT SUSCEPT. } & \text { DESCRIPTION } & \text { FACIES }\end{array}$

$\begin{array}{ccc}\text { AGE, yrs BP } & \text { \% SAND } \\ \text { Min } & \text { Max } & \text { CONTENT }\end{array}$

\begin{tabular}{|c|c|c|c|c|c|c|}
\hline Qbs & $\mathbf{H}$ & Beach sand & current beach & 1 & $20 ?$ & $>98$ \\
\hline Qds & $\mathbf{M}-\mathbf{H}$ & Young dunes & eolian sand, active & 1 & 5000 & $>95$ \\
\hline Qfd & M-L & Flandrian dunes & eolian, stabilized now & 5000 & 10000 & $>90$ \\
\hline $\mathbf{Q b}$ & $\mathbf{M}-\mathbf{H}$ & Basin deposits & fluvial, overbank & 1 & 10000 & $25-50$ \\
\hline Qal & $\mathbf{M}-\mathbf{H}$ & Undif. Alluvium & channel \& overbank & 1 & 10000 & $50-75$ \\
\hline Qf & $\mathbf{L}-\mathbf{M}$ & Alluvial fan deposits & alluvial fan & 1 & 5000 & $25-75$ \\
\hline Qyf & VH-H & Younger floodplain & channel \& point bar & 1 & 500 & $>90$ \\
\hline Qyfa & $\mathbf{L}$ & thin veneer of Qyf & levee, overbank & 1 & 500 & 50 \\
\hline Qof & $\mathbf{M}$ & Older floodplain & overbank sand, silt & 500 & 5000 & 25 \\
\hline Qc & $\mathbf{L}$ & Colluvium & hillslope, mixed sed. & 1 & 5000 & $0-25$ \\
\hline Qcf & $\mathbf{H}$ & Channel fill deposits & clays, silty clays, silt & 1 & 5000 & $75-100$ \\
\hline Qf & L-H & Artificial fill & homocene, mixed sed & 1 & 100 & $0-100$ \\
\hline Qls & $\mathrm{L}$ & Landslide deposits & hillslope, mixed sed. & 1 & 50000 & $0-25$ \\
\hline Qod1 & L & Younger coastal dunes & eolian sand & 10000 & 30000 & $>95$ \\
\hline Qod2 & L & Older coastal dunes & eolian sand & 30000 & 80000 & $>95$ \\
\hline Qch & L & Chualar deposits & alluvial fan & 30000 & 80000 & $25-75$ \\
\hline Qt & L & Terraces, undiff. & fluvial, undifferent. & 30000 & 1600000 & $0-100$ \\
\hline Qes & $\mathbf{L}-\mathbf{M}$ & Sunset Beach deposits & eolian sand & 20000 & 125000 & $>95$ \\
\hline Qyt & $\mathbf{L}$ & Younger terrace dep. & old sloughs, paludal & 30000 & 80000 & $0-25$ \\
\hline Qoe & $\mathrm{L}$ & Older eolian deposits & eolian sand & 125000 & $250000 ?$ & $>95$ \\
\hline Qtc & $\mathrm{L}$ & Castroville terrace & fluvial undiff & 125000 & $>1600000$ & $50-75$ \\
\hline Qan1 & L & Antioch Terrace & fluvial undiff & $>50000$ & $>1600000$ & $50-75$ \\
\hline Qan2 & L & Antioch Terrace & fluvial undiff & $>50000$ & $>1600000$ & $50-75$ \\
\hline Qan3 & L & Antioch Terrace & fluvial undiff & $>50000$ & $>1600000$ & $50-75$ \\
\hline Qem & L & Manresa Dunes & eolian sand & 50000 & 80000 & $>95$ \\
\hline Qwf & L & Watsonville Terr, fluv & fluvial undiff & 80000 & 125000 & $50-75$ \\
\hline Qwa & $\mathrm{L}$ & Watsonville Terr, fan & alluvial fan & 80000 & 125000 & $25-50$ \\
\hline Qsc & L & Santa Cruz terrace & marine, fluvial & 80000 & 125000 & $50-75$ \\
\hline Qp & $\mathrm{L}$ & Placentia fan deposits & alluvial fan & $>125000$ & $>1600000$ & $25-50$ \\
\hline Qcu & $\mathrm{L}$ & Coastal terrace, undif. & marine, fluvial & $>35000$ & $>1600000$ & $50-75$ \\
\hline $\mathrm{Qa}$ & $\mathrm{L}$ & Aromas sand & eol, fluv. undiff & $>250000$ & $>1600000$ & $25-100$ \\
\hline Qae & $L$ & Aromas - eolian dep & eolian sand & $>250000$ & $>1600000$ & $75-100$ \\
\hline Qaf & L & Aromas - fluvial dep & fluvial deposits & $>250000$ & $>1600000$ & $50-75$ \\
\hline Qgl & $\mathbf{L}$ & Gloria Fan deposits & alluvial fan & $>250000$ & $>1600000$ & $50-75$ \\
\hline QTc & $\mathbf{L}$ & Continental deposits & non-marine, undif & $>500,000$ & $>1600000$ & $50-75$ \\
\hline $\mathbf{p Q}$ & VL & Pre-Quaternary undif & sed, ign, meta rocks & $>1600000$ & $>1600000$ & $0-25$ \\
\hline
\end{tabular}

* compiled by Tinsley. For descriptions of all units, see Dupré and Tinsley (1980); for detailed descriptions of the 12 youngest units (top), used in regression (Table 5) see Table 3. 


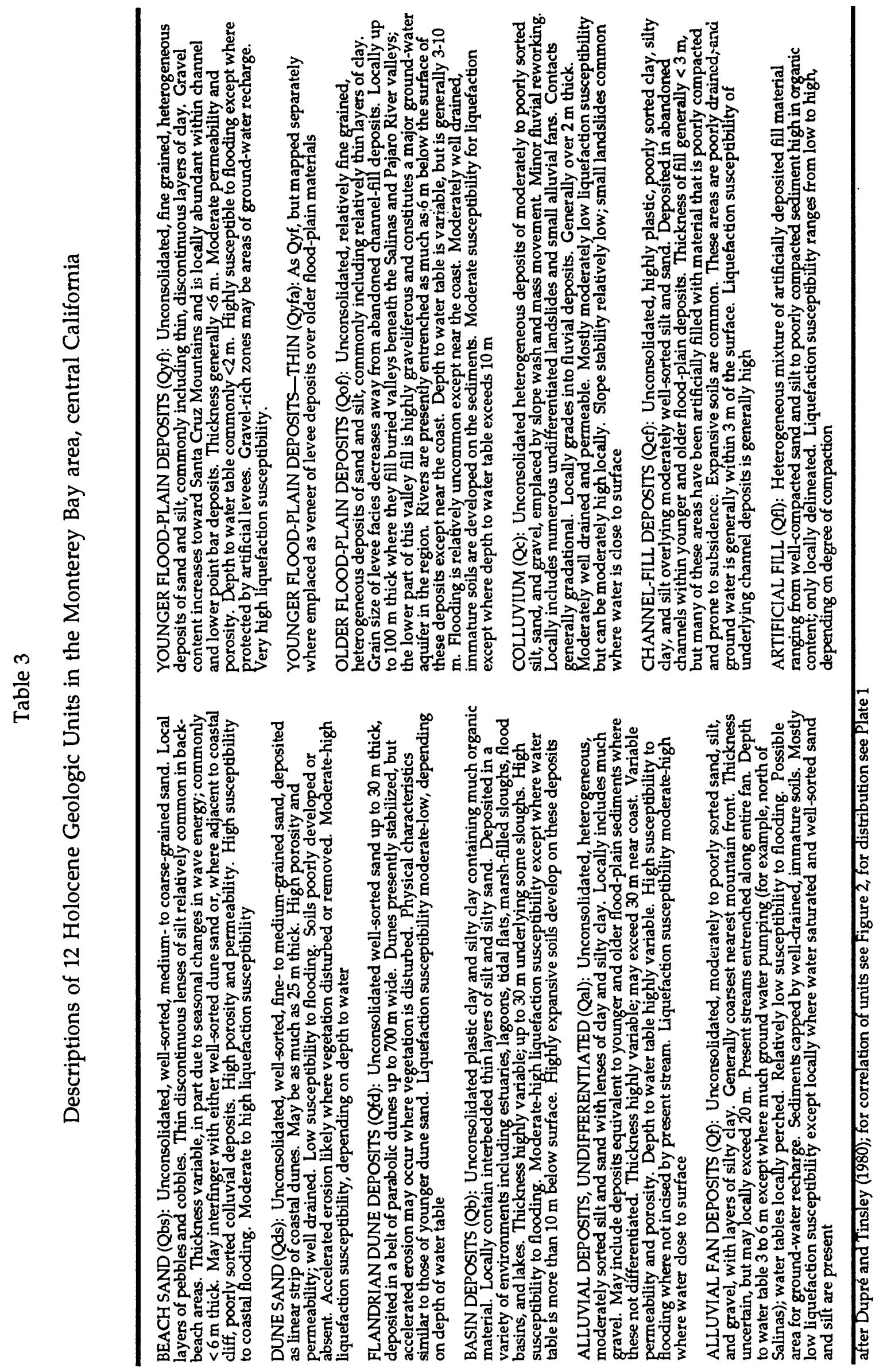


zonation, including the mapping of soil liquefaction and its effects, have begun to incorporate such advanced technologies as artificial intelligence (Shah and others, 1991) and fuzzy set theory (Juang and Elton, 1991).

Our threshold and susceptibility calculations were not made in the GIS, but all contributing data were organized within it and the resulting maps were created and printed by it. We used the Arc/Info GIS (ESRI, 1992) and employed both its raster (rectangular grid-cell) and vector (polygon) data structures in handling information input and c-atput. For example, the geologic-unit boundaries and stream courses were input as vector data and the topographic heights in raster format. The hardware platform is a UNIX-based workstation network, employing a Sun 4/380 SPARC file server and Visual TX600C display terminals. The storage capacity required for our data and computations is 100 megabytes. The output device is a Precision Image 636 color electrostatic drum-plotter with a sheet capacity of three by four feet and a resolution of 400 dots per inch. The values of map information manipulated in this system were arrayed in a rectangular grid of one-hectare cells. This $100-\mathrm{m}$ spatial scale is a good compromise between desired level of detail and computational burden (Bernknopf and others, 1988; Mark, 1992). Our six-quadrangle sample in the Monterey Bay area includes 75,072 such cells.

\section{SELECTION OF VARIABLES}

Both the threshold identification and the regression equation for modeling lateralspread susceptibility required variables assigned to or calculated for each of the 75,072 1-ha parcels. The threshold criteria were maximum age of the geologic units, land-surface slope, and whether the materials were consolidated. For our probit estimate of susceptibility, the dependent variable is categorical-each cell lies within a mapped geologic unit that has been judged either most likely to spread or less likely to fail in the event of a large earthquake. The four independent variables, expressed as continuous values, are average age and sand content of the geologic units, horizontal distance to nearest open water, and land-surface slope.

To create an approach for mapping susceptibility to lateral spreading that is widely applicable (and by non-geologists), several requirements and assumptions were built into the rationale for our model. Among these is minimizing the amount of technical expertise needed to assess an area (Juang and Elton, 1991). Accordingly, the dependent variable for the probit analysis requires only a geologic map and a geologist's (or other qualified expert's) prior judgment of the one or two units most likely to liquefy and spreadthe sole comparative (i.e., subjective) ranking needed (Tables 1 and 3 ). However, the geologic mapping must be detailed (1:24,000 is the minimum scale) and recognition of subtle distinctions among Quaternary deposits is essential (e.g., Dupré and Tinsley, 1980). Although the mapper (or qualified engineer) must be sufficiently familiar with the lateralspreading process to pick the mapped unit(s) most likely to fail in a severe earthquake, evidence in the historical record, if available, helps make this a straightforward distinction. A weakness of the approach is the heterogeneity of geologic units and thus the importance of mapping individual facies, the major spatial variations in physical properties within a given unit. We caution that an engineer or other non-geologist may not be able to evaluate a geologic map without an understanding of sedimentary facies (Tables 2 and 3).

The four variables adopted as determinants of lateral spreading (and surrogates for geotechnical measures) are intrinsic properties of the geologic materials and their physiographic setting. They either are or could be obtained readily from existing maps or calculated in digital-map form from other data. Age and sand content come from descriptions of geologic map units and accompanying field sampling. Distance to nearest surface water or free face can be calculated in the GIS from digital USGS maps of streams and drainage channels. Slope angle is computed in the GIS from a digitized topographic map available from USGS. 
Depth to shallow or perched ground water is a critical variable that is not commonly available, for either the Monterey study area or other locales that need to be assessed for susceptibility to lateral spreading. As a provisional surrogate for this property in the experiments leading up to Plate 1 , we worked with elevation above local base-level, in the Monterey Bay area, sea level-also calculated in the GIS from a digitized contour map. Because both susceptible and nonsusceptible sites lie at similar elevations (Table 4), the measure did not perform well in the regression equation and was dropped from the final model. However, we include information on elevation here because we believe that eventually it can be combined with data on stream elevation and nonsystematic samplings of wells and other borings to model estimates of depth to ground water, probably through Kriging (Burrough, p. 158-162).

\section{OBSERVATIONS}

\section{Geologic Map Units}

The distribution of Quaternary deposits in the study area supplies critical information about possible effects and potential hazards of landscape-forming processes as they relate to land use. Dupré and Tinsley (1980) identified 50 geologic formations and subdivisions of them, including queried occurrences (Table 4), simplified to 36 map units in Table 2 and Figure 2. The units range in age from pre-Quaternary to latest Holocene and include bedrock and unconsolidated materials. The units were defined and delimited on the basis of their relative age and depositional environment. Each unit generally has a restricted assemblage of physical properties (Table 2). Where these properties vary, many do so in a systematic and predictable way. Dupré and Tinsley's (1980) description of each geologic unit, here reproduced for the 12 most critical to our study (Table 3), includes a brief summary of selected physical properties of the deposits (e.g., dominant particle size), their variability, relation to other geologic units, and-although not part of a standard description of map units-relative susceptibility to liquefaction and lateral spreading.
We entered all 50 geologic units and subunits into the GIS as one Arc/Info directory of vector data, or coverage [designated GEOL], per quadrangle. This was the most timeconsuming and labor-intensive phase of the study. It was accomplished by tracing geologic contacts on transparent overlays, from enlargements of the original six Dupré and Tinsley (1980) manuscript quadrangles. The six tracings were converted to digital data ( 300 dots per inch) on a Tektronix 4991 autovectorizing scanner (Soller and others, 1990), transformed to Arc/Info coverages on the Sun workstation system, edited for accuracy, and mosaicked into a single coverage. For subsequent calculations, each geologic unit was assigned an identifying integer. Also, some of the units' descriptive characteristics (e.g., age, sand content) were selected as independent variables.

\section{Soil Liquefaction and the Lateral-Spreading Hazard}

Expert judgment of liquefaction potential and the actual lateral-spreading hazard is arguably the most crucial element of our model. The study area has been evaluated with respect to both characteristics, from field observations, and the two rankings are in substantial agreement (Table 5 and Figure 4). Dupré and Tinsley (1980) mapped the liquefaction potential for geologic units in the area, given a repeat of the 1906 earthquake on the San Andreas fault (Table 1). From both qualitative and quantitative criteria they estimated the susceptibility to liquefaction as very high, high, moderate, low, or very low. (An analogous ranking, by "geomorphological conditions", is cited for a Japanese case by Ishihara and Yasuda, 1991, p. 713.) The criteria of Dupré and Tinsley included age and mode of deposition of the sediments, distribution of sand and silt, physical properties of the sediments, proximity of the water table, and historical evidence of liquefaction. Dupré and Tinsley drew their maps of liquefaction potential on the basis of correlations between the areal distribution of geologic units and their relative susceptibility to liquefaction. 
Table 4

Mean Values of Five Independent Variables for 50 Geologic Map Units in the Monterey Bay area, central California*

\begin{tabular}{|c|c|c|c|c|c|c|}
\hline $\begin{array}{l}\text { Geologic } \\
\text { Map } \\
\text { Unit }\end{array}$ & $\begin{array}{c}\text { Number. } \\
\text { of } \\
\text { Cells }\end{array}$ & $\begin{array}{l}\text { Age, } \\
\text { log yrs } \\
\text { BP }\end{array}$ & $\begin{array}{c}\text { Ave. Sand } \\
\text { Content, } \\
\%\end{array}$ & $\begin{array}{l}\text { Distance } \\
\text { to Water, } \\
\text { ln } \mathrm{m}\end{array}$ & $\begin{array}{c}\text { Ground } \\
\text { Slope, } \\
\text { ln \% }\end{array}$ & $\begin{array}{c}\text { Height above } \\
\text { local base } \\
\text { level, In } \mathrm{m}\end{array}$ \\
\hline 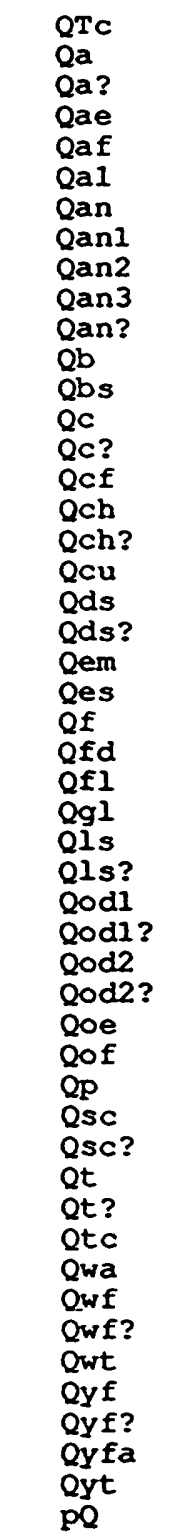 & $\begin{array}{r}64 \\
6,056 \\
11 \\
3,317 \\
2,995 \\
2,053 \\
3,357 \\
503 \\
230 \\
619 \\
78 \\
8,094 \\
357 \\
3,306 \\
14 \\
572 \\
2,069 \\
178 \\
497 \\
317 \\
77 \\
2,196 \\
356 \\
852 \\
470 \\
128 \\
863 \\
584 \\
3 \\
2,140 \\
24 \\
3,721 \\
259 \\
1,405 \\
8,904 \\
257 \\
993 \\
6,6 \\
1,435 \\
7 \\
271 \\
904 \\
2,384 \\
71 \\
2,654 \\
5,856 \\
375 \\
782\end{array}$ & $\begin{array}{l}5.950 \\
5.800 \\
5.800 \\
5.800 \\
5.800 \\
2.000 \\
5.451 \\
5.451 \\
5.451 \\
5.451 \\
5.451 \\
2.000 \\
0.650 \\
1.849 \\
1.849 \\
1.849 \\
4.689 \\
4.689 \\
5.373 \\
1.849 \\
1.849 \\
4.800 \\
4.698 \\
1.849 \\
3.849 \\
1.000 \\
5.800 \\
2.349 \\
2.349 \\
4.238 \\
4.238 \\
4.689 \\
4.689 \\
5.247 \\
3.199 \\
5.650 \\
4.999 \\
4.999 \\
5.340 \\
5.340 \\
5.650 \\
4.999 \\
4.94939 \\
4.9999 \\
1.349\end{array}$ & $\begin{array}{l}0.625 \\
0.625 \\
0.625 \\
0.875 \\
0.625 \\
0.625 \\
0.625 \\
0.625 \\
0.625 \\
0.625 \\
0.625 \\
0.375 \\
0.990 \\
0.125 \\
0.125 \\
0.875 \\
0.500 \\
0.500 \\
0.625 \\
0.975 \\
0.975 \\
0.975 \\
0.975 \\
0.500 \\
0.950 \\
0.500 \\
0.625 \\
0.125 \\
0.125 \\
0.975 \\
0.975 \\
0.975 \\
0.975 \\
0.975 \\
0.250 \\
0.375 \\
0.625 \\
0.625 \\
0.500 \\
0.500 \\
0.625 \\
0.375 \\
0.625 \\
0.625 \\
0.625 \\
0.950 \\
0.950 \\
0.500 \\
0.125 \\
0.125\end{array}$ & $\begin{array}{l}4.699 \\
5.320 \\
4.706 \\
6.035 \\
4.968 \\
2.401 \\
5.129 \\
5.315 \\
5.299 \\
5.589 \\
6.559 \\
3.531 \\
0.116 \\
4.766 \\
6.175 \\
2.093 \\
5.507 \\
4.999 \\
5.022 \\
2.966 \\
0.000 \\
5.095 \\
5.301 \\
4.532 \\
3.994 \\
4.379 \\
4.770 \\
4.550 \\
5.889 \\
7.049 \\
8.303 \\
6.828 \\
6.402 \\
5.473 \\
5.052 \\
4.443 \\
4.864 \\
6.174 \\
4.730 \\
4.409 \\
4.962 \\
4.310 \\
5.066 \\
5.677 \\
4.522 \\
2.883 \\
5.434 \\
5.116 \\
5.014 \\
4.465\end{array}$ & $\begin{array}{r}2.249 \\
2.125 \\
2.476 \\
1.846 \\
2.068 \\
1.248 \\
0.361 \\
-0.033 \\
0.556 \\
1.154 \\
-0.500 \\
-0.422 \\
0.420 \\
2.093 \\
2.573 \\
-0.831 \\
-0.263 \\
0.035 \\
1.388 \\
0.070 \\
-2.413 \\
1.108 \\
1.161 \\
0.883 \\
1.422 \\
0.167 \\
1.701 \\
2.807 \\
2.361 \\
0.799 \\
2.065 \\
0.896 \\
1.382 \\
1.444 \\
-0.581 \\
0.890 \\
0.430 \\
0.552 \\
1.521 \\
1.045 \\
2.375 \\
0.864 \\
1.078 \\
1.154 \\
1.142 \\
-0.139 \\
0.000 \\
-0.226 \\
1.213 \\
2.778\end{array}$ & $\begin{array}{r}4.573 \\
4.430 \\
3.585 \\
4.556 \\
4.382 \\
3.584 \\
2.720 \\
1.382 \\
2.093 \\
2.686 \\
2.519 \\
1.126 \\
-1.440 \\
4.203 \\
4.064 \\
1.342 \\
3.280 \\
3.180 \\
3.795 \\
0.975 \\
-1.316 \\
3.582 \\
3.627 \\
3.436 \\
2.623 \\
1.344 \\
3.846 \\
4.747 \\
2.851 \\
3.481 \\
4.804 \\
3.697 \\
4.285 \\
3.879 \\
2.430 \\
3.143 \\
1.824 \\
0.992 \\
3.520 \\
3.026 \\
4.502 \\
3.561 \\
3.586 \\
2.540 \\
3.696 \\
2.064 \\
3.029 \\
1.969 \\
2.489 \\
5.508\end{array}$ \\
\hline
\end{tabular}

Units Qan and Qwt, undifferentiated terrace deposits of Antioch and Watsonville, respectively, were mapped by Dupré and Tinsley (1980) but not listed explicitly in their explanation or in our Table 2. Height above local base level was omitted from the final model (see discussion in text). 


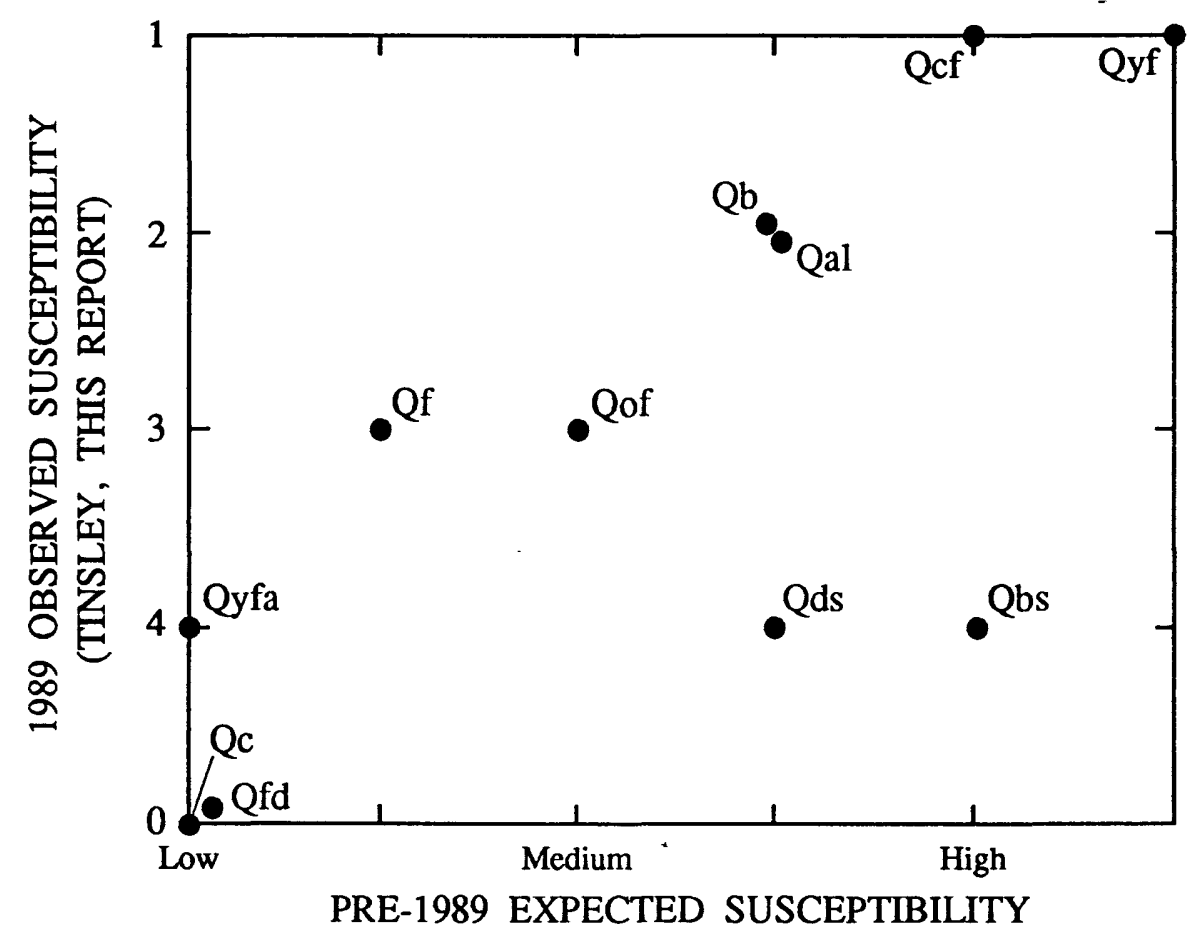

(DUPRÉ AND TINSLEY, 1980)

Figure 4. Rankings of expected susceptibility to earthquake-induced soil liquefaction (horizontal axis) and observed susceptibility to lateral-spread ground failure (vertical axis) for 11 geologic map units (artificial fill omitted) in the Monterey Bay area, California-category 1, most susceptible; 4 , least susceptible; 0 , not susceptible. See text and Tables 1 and 5 . 
In the $1989 M_{w}=6.9$ Loma Prieta earthquake, many sites along the Monterey Bay coast liquefied and failed by lateral spreading. For this study, Tinsley devised a four-part classification of the spreading hazard for nine of the $\mathbf{1 2}$ Holocene units in the study area that he deemed susceptible, based on observations of lateral spreads in the Loma Prieta event (Tables 3 and 5). Tinsley's scale of the spreading hazard, from 1 (most susceptible) to 4 (least susceptible), is comparable to that of Dupré and Tinsley (1980) for liquefaction potential, save that units Qds (dune sand) and $\mathrm{Qbs}$ (beach sand) were reclassified as much less hazardous (category 4) to reflect the absence of observed failures in 1989 (almost certainly due to low water content). Two other Holocene units Qc (colluvium) and Qfd (Flandrian dunes) included in our regression calculation were ranked by Tinsley as 0 , or not susceptible, in Table 3 on the basis of their overall steep slopes and the substantial depths to water table. The third added Holocene unit, artificial fill (Qfl) varies so widely in physical characteristics (Table 3 ) that it was not ranked. Figure 4 shows the overall agreement of the two rankings for the 11 naturally occurring units. We labelled each of the 36 geologic units with its class from Tinsley's ranking of lateral-spread susceptibility (Table 5) and entered this information into the GIS as a separate coverage [CLASS]. The nine units ranked 1-4 were further coded UNIT in the GIS.

Tinsley and others (in press) mapped both lateral spreads (Plate 1) and sand boils (not shown) resulting from the Loma Prieta event. The two consequences of liquefaction are similarly distributed overall. These failures also occurred in the same areas that liquefied in 1906, mainly bordering the Salinas and Pajaro rivers. Most lateral spreads were identified in units classified by Dupré and Tinsley (1980) as having high and very high susceptibility to liquefaction, e.g. units Qyf and Qcf (Table 3). Head scarps of the 1989 Loma Prieta lateral spreads, observed in 1131 -ha cells, were found in only five units (Table 5): Qyf ( $n=81$ cells), Qcf $(n=10)$, Qof $(n=9), Q b(n=7)$, and Qds $(n=6)$. (These units are similar to those observed to fail in the 1964 Niigata earthquake; Ishihara and Yasuda, 1991, p. 711.) Lateral spreading commonly involves terrain well beyond the head scarps, however, and cells adjacent to the 113 with head scarps also contained ground that moved in the 1989 spreads. We digitized the location and extent of all affected terrain and entered the 363 resulting parcels (now eight units, Table 5) into the GIS as DAM. Two cells are in artificial fill (Qfl), not ranked for susceptibility. All cells are coded categorically, as either 1 or 0 (i.e., failure/ no failure); positive values of DAM (coded 1) do not reflect the actual fraction of each cell affected by spreading - which varied widely.

The hazard of lateral spreading may also be expressed numerically, as "observed relative susceptibility", by the spatial frequency of failures during a specific earthquake. For each geologic unit in the study area, we compared the number of 1-ha cells affected by lateral spreading in the 1989 Loma Prieta earthquake to the total number of cells estimated from our criteria to be susceptible (Table 5). The resulting percentages, ranging from $8.2 \%$ to $<0.5 \%$, rank the eight affected units in the following descending order: Qfy, Qds, Qcf, Qfl, Qyfa, Qbs, Qof, and Qb. We caution that such figures can be misleading. They are based on small-number samples and in the case of dune sand (Qds) the failures reflect the more susceptible deposits that lie beneath or adjacent to the classified surface materialsthe dune sand itself did not liquefy. The resulting ranking of units, by failed cells as a percentage of all cells, somewhat resembles those of Dupré and Tinsley (1980) and Tinsley (this report), but no functional relations are evident (Table 5).

\section{Age of Geologic Units}

Absolute ages, in years BP, for each of the 36 geologic units were compiled from the investigations by Dupré and Tinsley (unpublished observations), assigned to all 1ha cells in that unit, and added to the GIS. Two separate Arc/Info coverages were created, for maximum and minimum ages (Table 2), and coded as XAGE and MAGE, respectively. Averages of these extreme values, used in the final calculation for the 12 susceptible units (Table 4), range from 5 yrs BP (beach sand, Qbs) 
and 10 yrs BP (artificial fill, Qfl) to 7000 yrs BP (Flandrian dunes, Qfd) and 1600 yrs BP (older flood-plain deposits, Qof).

\section{Sand Content of Deposits}

In the absence of such ideal characteristics as density state, some measure of size sorting-here percentage of sand-is perhaps the most sensitive indicator of a sedimentary deposit's tendency to spread in an earthquake. Sand content is limited in its predictive capability, however, because silt also can liquefy and be involved in ground failure. To generalize on the role of sorting in this process: gravels are normally difficult to liquefy and spread (they are so coarse that they drain too rapidly to retain water); cohesive soils containing significant clay normally are not liquefiable and prone to spreading; where clay is absent, sand content can serve as a useful indicator of susceptibility. Laterally-accreted fluvial facies are largely clay-free, because clays and fine silts are carried through the stream reach as suspended load and are deposited in the overbank facies during floods. These vagaries of meanderingstream deposition caution that our statistical model may not always be appropriate to alluvial fans, playas, or some deltas and will have to be applied with due restraint.

Because fluvial deposits may be heterogeneous, the sand content of a unit can vary widely within a small area. Accordingly, maximum and minimum percentages of sand in each geologic unit mapped by Dupré and Tinsley (1980) were estimated from field observations and some laboratory analyses by Tinsley for the 36 units and compiled in Table 2. Using the GIS-encoded geologic map as a template, we assigned values of maximum [XSD] and minimum [MSD] percent sand, by Arc/Info, to all 1-ha cells in each unit.

Averages of these extreme values calculated for the final model (Table 4) range from $12.5 \%$ (colluvium, $Q_{c}$ ) and 25\% (older flood-plain, Qof) to essentially $100 \%$ (beach sand, Qbs) and 98\% (dune sand, Qds).

\section{Land-Surface Slope}

We calculated the angle of surface slope as an Arc/Info grid coverage [SLOPE] for each 1ha cell from a digital elevation model (DEM), a rectangular-grid array of terrain heights. The master DEM was assembled from six constituent 1:24,000-scale quadrangle-based DEM's published by the U.S. Geological Survey. Original DEM resolution was $30 \mathrm{~m}$. We first computed slope on a $3 \times 3(90 \mathrm{~m})$ sub-grid or, sampling window, and then recomputed (regridded) it to our standard $100 \mathrm{~m}$ interval. Average slope at 1 ha for geologic units (Table 4) ranges from $0.6 \%$ (channel fill, Qcf) and $0.8 \%$ (older flood plain, Qof) to $4.2 \%$ (colluvium) and 3.6\% (Flandrian dunes, Qfd).

Despite correlation of very low ground slope with lateral-spreading in the coastal lowlands of California, slope angle has disadvantages as a predictive variable. One such drawback is that the slopes of most stream banks, where particularly severe effects of lateral spreading commonly are observed, are steep rather than nearly horizontal. We retained slope as a parameter because this inconsistency affects only a small fraction of the observations and thus did not seriously affect the resulting model and map for the Monterey area (Plate 1).

DEM accuracy is another problem.

Because the DEM's available for the study area were generated by photogrammetric scanning (an imprecise procedure since supplemented at USGS by the more accurate technique of contourfollowing), many of the gridded heights are locally inaccurate. The resulting errors, overly steep slopes (manifested as horizontal bands and rectilinear texture in derived maps), can be serious in areas of low relief-which commonly host the sites most likely to liquefy. To partly compensate for this inaccuracy, and thus somewhat diminish the resulting slope values, we smoothed the raw DEM with the $3 \times 3$ window. The procedure was not entirely successful; some rectilinear texture, most notably along quadrangle boundaries, can still be detected in Plate 1 and other maps (not shown) resulting from our experiments. Although better DEM's would improve the slope data, performance of the resulting model 


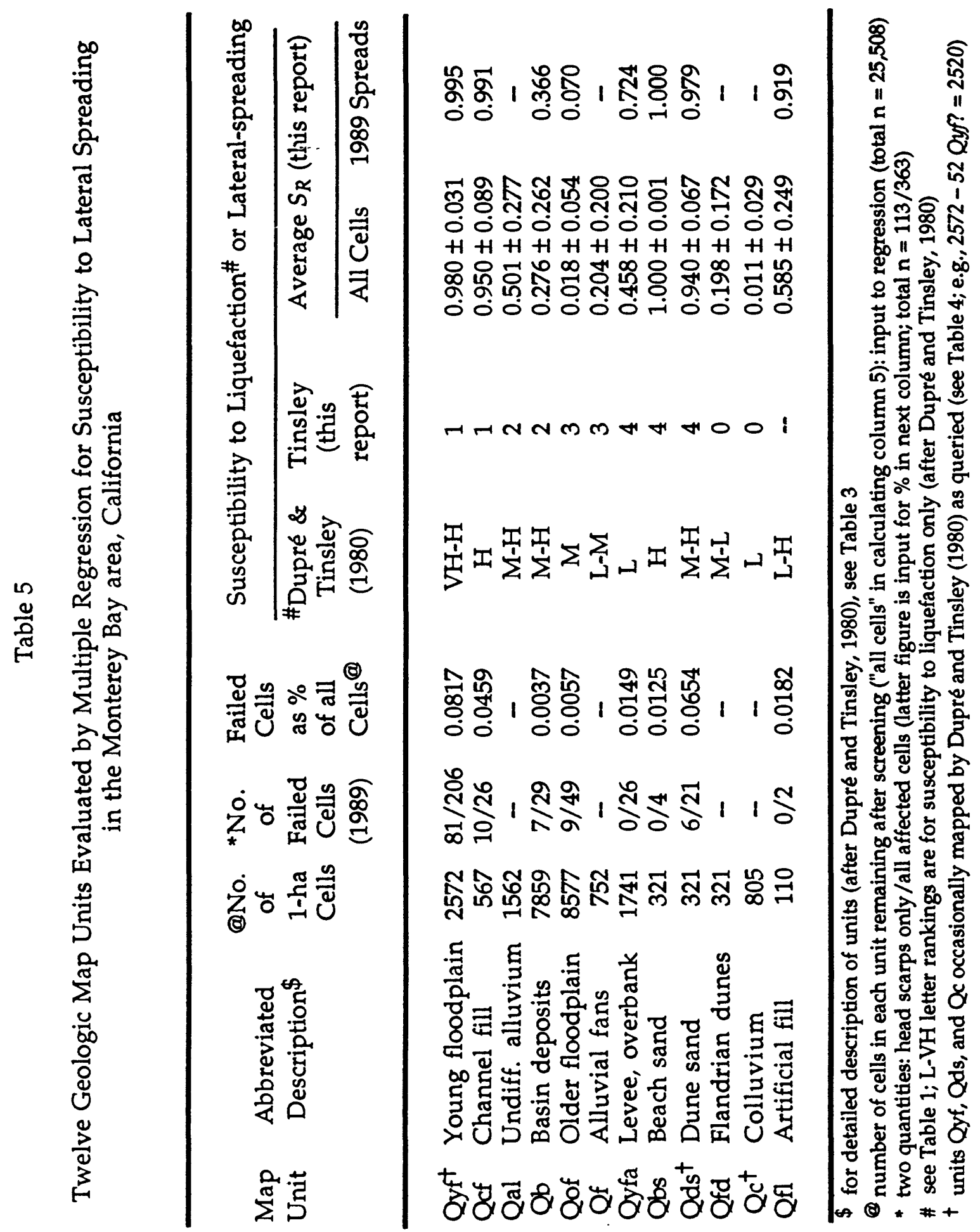



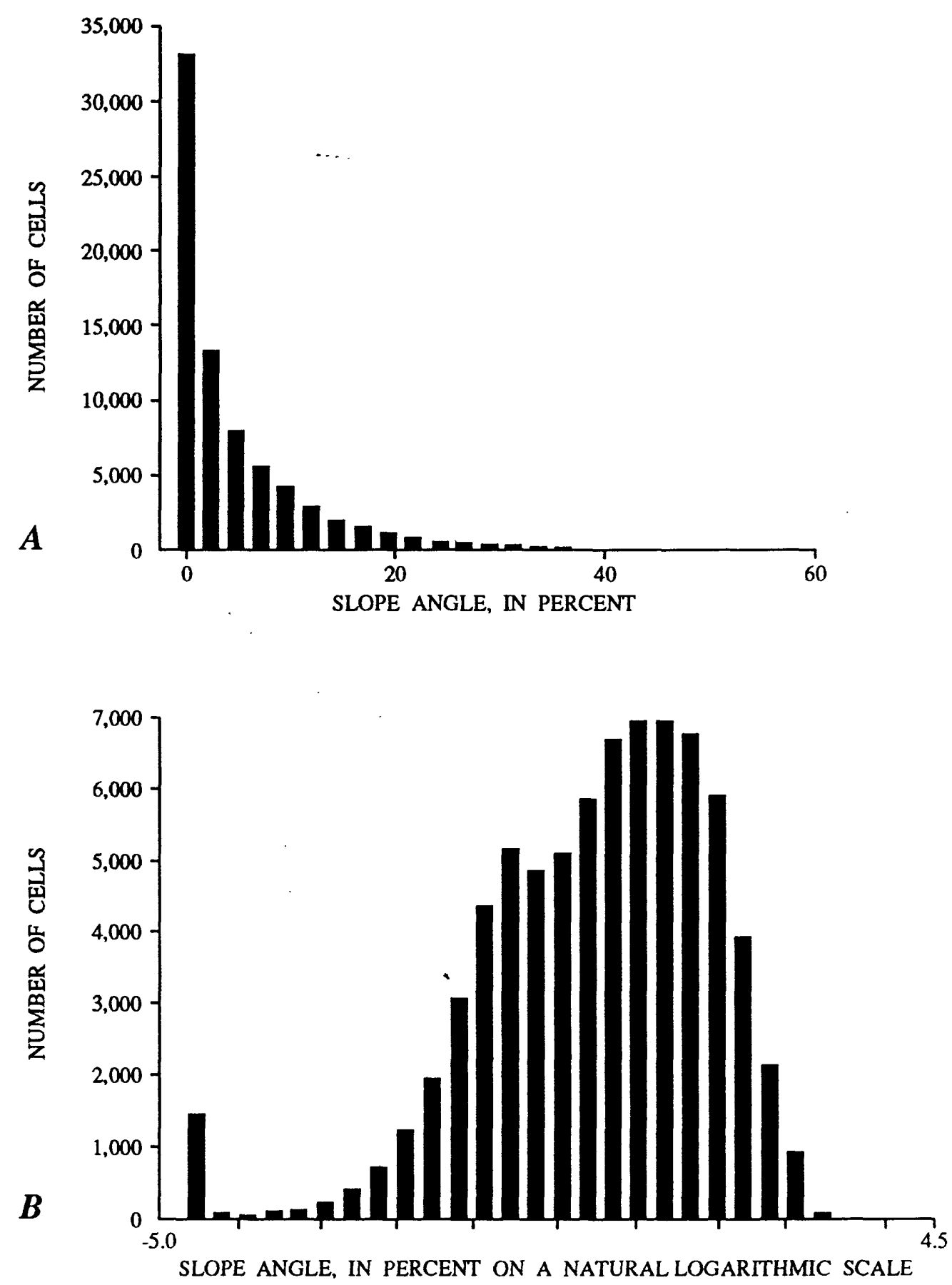

Figure 5. Transformation of input variables for probit regression, exemplified by slope angle. A. Arithmetic frequency distribution of slope (\%) for 25,508 map cells. B. Slope transformed to natural (Naperian) logarithms $\left(l_{n} \%\right)$. 
suggests that the values calculated here are accurate enough for our current objectives.

\section{Distance to Surface Water}

In the Monterey Bay area, unconfined vertical surfaces that can move horizontally in the event of an earthquake are mostly the banks of present and former stream channels and drainage ditches. Although distance to surface water is an indirect variable that in no way controls susceptibility per se, the correlation between these two features and lateral spreading is a good one in the study area. The channels and ditches, represented by blue lines on USGS 7.5' quadrangles and available in electronically-stored format as digital line graphs (DLG's), were compiled as an Arc/Info coverage. The horizontal distance of each 1-ha cell to the nearest blue line, or occurrence of surface water, was then calculated in Arc/Info and compiled as a derived grid coverage [DIS]. Average distances (Table 4) range from $4 \mathrm{~m}$ (beach sand, Qbs) and $80 \mathrm{~m}$ (dune sand, Qds) to $364 \mathrm{~m}$ (older flood plain, Qof) and $296 \mathrm{~m}$ (thin levee and overbank deposits, Qyfa).

\section{Ground Elevation}

Height above local base level (the lowest elevation to which stream erosion has cut), in this area sea level, was a provisional surrogate for depth to ground water - an important but unavailable quantity. We dropped it from the final calculation for Plate 1. Although a poor replacement for the latter measure, in the Monterey Bay area enough low elevations commonly are associated with stream channels and hence with young, saturated, sandy deposits-the materials most likely to liquefy-to encourage experimentation with terrain height. Our estimates of height, computed for each 1-ha cell in Arc/Info and compiled as a grid coverage [ELEV], were taken from the same smoothed DEM from which we obtained land-surface slope (Table 4). The resulting heights are subject to the errors described for slope. Average height ranges from essentially sea level (beach sand, Qbs) and $3 \mathrm{~m}$ (dune sand, Qds) to $67 \mathrm{~m}$ (colluvium, Qc) and $36 \mathrm{~m}$ (undifferentiated alluvium, Qal).

\section{DATA PREPARATION}

None of the variables for the susceptibility calculation was manipulated in its original form. Multiple regression, like other multivariate procedures, is sensitive to the choice and frequency distribution of its constituent measures, and the uncritical input of highly correlated or skewed data can lead to a weak and unrealistic model (Gujarati, 1988, p. 340-341, 398-427). Previous work with principal-component and cluster analysis of crater landforms, for example, demonstrated the importance of eliminating the most disruptive effects of extreme values and outliers from the input distributions (Pike, 1980).

In modeling susceptibility to lateral spreading, we found that preprocessing the variables yielded more defensible results than the blind "objective" feeding of unexamined raw data into a computer. The shape of input frequency distributions, in particular, affected both the statistical validity and explanatory power of the susceptibility model. After much experimentation, we calculated centraltendency values for sand content [ASD] and age [MIDAGE] and transformed age, distance, and slope to logarithms. The respective variables for age, slope, and distance for all 75,072 1-ha cells are coded MIDAGE, LSLOPE, and LDIS. We calculated mean values of these variables (and elevation, not used for the final model) for each of the 36 geologic map units, the 12 queried units, and two undifferentiated units $Q$ an and Qwt (Table 4).

Maximum and minimum values of both geologic-unit age and sand content vary widely (Table 2). To obtain more stable estimates of these variables from the extremes, we averaged the maximum and minimum percentages of sand [XSD, MSD] to yield ASD, and took the midpoint of the logarithms (base 10) of maximum and minimum ages [XAGE, MAGE] to obtain the geometric midpoint [MIDAGE]. The latter transformation thus places emphasis on the younger deposits within a given unit. 
Transforming three of the variables to logarithms, to remove severe skew, improved their capability to predict locations of lateral spreading. The variables were first examined for their relation to the range of liquefaction susceptibility on the 5-grade ordinal scale of Dupré and Tinsley (1980) (Table 1). The mean or median of each variable computed for each geologic unit was plotted against the five values of liquefaction susceptibility (actually seven, as some units have combined rankings), assuming equal intervals for susceptibility. Although scatter is considerable, all four arithmetic plots (not shown) display functional relations. Three of the independent variables are severely skewed, however, and all of the trends save that for sand content are curvilinear. Replotting the three variables in logarithmic space [slope and distance in SHAZAM, which uses natural (Naperian) logarithms: $\log _{e}$, or ln] markedly diminished skew (Burmaster and Lehr, 1991). Figure 5 shows this contrast for ground slope. The resulting semi-logarithmic plots of susceptibility against the transformed variables (not shown) revealed both reduced scatter and a more linear trend. Although we did not attempt to achieve normality for each variable, the reduction of severe skew did convert the three variables (plus elevation, later eliminated) into symmetric distributions that strengthened the regression model.

The transformed data are summarized for each geologic unit in Table 4. Many values of terrain slope, elevation, and distance to open water are zero. To avoid the impossibility of taking the logarithm of zero, we arbitrarily designated all such values $0.1 \%, 0.1$ meters above sea level, and $0.06 \mathrm{~km}$, respectively. We tried distance and height values of 0.01 and 0.001 , but both alternatives to zero unduly distorted the frequency distributions and were dropped from further consideration.

\section{ESTIMATING LATERAL-SPREAD SUSCEPTIBILITY}

We experimented with two methods of mapping susceptibility to lateral spreading from the numerical data summarized in Table 4: logit or probit regression (the techniques are quite similar; Bernknopf and others, 1988; Mark, 1992) and a combination of threshold screening and regression. Both methods yielded satisfactory, even excellent, maps in that high susceptibility values resulting from the calculations coincided with specific sites and geologic units recognized in the field as hazardous. Low susceptibility values coincided with less hazardous and nonhazardous areas. We chose the combination procedure over the single regression for several reasons:

Our logit regressions, which were calculated mainly on age of the geologic units, the distance of each 1-ha cell from surface water, and the four-fold susceptibility ranking of Tinsley (Table 5), took as their dependent variable the 363 cells hosting lateral spreads in the 1989 Loma Prieta earthquake. The regressions were performed on those cells in the study area that were not eliminated by a ground-slope threshold $\left(3^{\circ}\right)$-computed using data from the obsolete U.S. Army Defense Mapping Agency 1:250,000-scale DEM (available from USGS) at 3 arc-seconds (about $90 \mathrm{~m}$ ) resolution. Although the resulting maps (not shown) are excellent and could well serve to calibrate the results of our other models, the 363 damaged cells are specific to the performance of sedimentary deposits in coastal Monterey County and in just one earthquake. Accordingly, the logit model would be difficult, even impossible, to transfer to areas lacking such an excellent set of recent lateral spreads to serve as the dependent variable - and thus is not portable, one of the main objectives of the study.

We experimented extensively with probit regression to generate a nonzero susceptibility value for every cell in the study area. The probit calculations also required only the simplest decision: that a geologic unit would or would not spread in a major earthquake. However, we believe it conceptually inconsistent and statistically incorrect to compute values of nonzero susceptibilityhowever low-for so many geologic units and specific sites that would not spread, even in the severest earthquake likely to strike the area. In particular, we thought it invalid to combine bedrock and unconsolidated sediments in the same statistical model. This judgment was 
confirmed by inconsistent statistics (i.e., incorrect signs of regression coefficients) that accompanied all such probit models derived from combined data, even though the patterns on the resulting maps (not shown) appeared to be very good (Bernknopf, Mark, and others, 1993).

Finally, we worked with the same twostep (probit) method described in the next two sections, but with observations of actual lateral-spread damage substituted for the expert judgments of relative susceptibility (compare, Bernknopf and others, 1988). These regressions are much like the logit models described above. In two experiments with this more direct approach to modeling susceptibility in the second step, we regressed the 363 1-ha cells hosting lateral spreading in the 1989 Loma Prieta earthquake on (1) the same suite of four empirical observations and also on (2) slope, distance, and presence/absence of the most susceptible units Qyf and Qcf. Although generating excellent-appearing maps of relative susceptibility, particularly in the low values of dune (Qds) and beach (Qbs) deposits in the second map (not shown), these two regressions were disappointing in other respects. Age of the geologic units was insignificant in the first model, a counterintuitive outcome, and neither regression explained more than a low $24 \%$ of the total variance in the observations. Again, because the dependent variable (the 363 damaged cells) is unique to the study area, the resulting model is probably not portable.

\section{Threshold Identification}

Enough is known about lateral spreading from field study in seismically active regions to identify materials in which the process is unlikely to occur. Such areas may be excluded from further evaluations of susceptibility on the basis of at least three criteriaconsolidation, age, and surface slope-all of which are used here. First, we omitted indurated materials, all pre-Quaternary units, from the analysis because lateral spreads do not occur in bedrock (Youd, 1973). Second, we removed all Pleistocene units because the low to very low liquefaction potential of pre-Holocene deposits is, according to the historical record in California, essentially zero (Youd and Hoose, 1978). [In the Monterey Bay area, moreover, all but two Pleistocene units (landslide deposits and younger coastal dunes) are much older than the 10,000-year Pleistocene/Holocene boundary (Table 2)]. Third, because lateral spreading in coastal California rarely occurs on materials with surface slope greater than $3^{\circ}$ (about 5.2\%) (Youd and Perkins, 1978; Tinsley and others, 1985), we excluded all such cells from further analysis. To allow for the inevitable smoothing of the data during slope computation, we used a cutoff ground-slope value of $6.0 \%$ (about $3.5^{\circ}$ ).

The three criteria removed two-thirds, or 49,564, of the 75,072 1-ha cells and all but 12 of the geologic units from further analysis. Of the excluded cells, 7182 are on indurated materials in highlands to the northeast (unit pQ), 38,254 are on Pleistocene units ( $>10,000$ yrs BP), and 4128 are in (comparatively) steep terrain on the 12 remaining Holocene units. Colluvium (unit $\mathrm{Qc})$, undifferentiated alluvium (Qa), and Flandrian dunes ( $Q f d)$-none of which failed by lateral spreading in the Loma Prieta earthquake -accounted for most (3141, or 76\%) of the 4128 "steep" cells (compare values of $n$ in Tables 4 and 5). These thresholds were implemented, within each regression run in SHAZAM, by the SKIPIF command (White and others, 1990) operating sequentially on files MAGE, XAGE, and SLOPE, respectively.

We assigned to each of the excluded cells a susceptibility value of zero (mapped as gray in Plate 1). Inspection of Plate 1 shows that the thresholding procedure is conservative. It has not eliminated areas likely to spread. None of these zero-value cells, even the 87 excluded cells located in the two most highly susceptible deposits Qyf ( $n=82$, or 3\% of this unit) and Qcf, $(n=5,1 \%)$ hosted lateral spreading in the 1989 Loma Prieta earthquake or, so far as we can ascertain from the historical record, in the 1906 San Francisco earthquake. 


\section{The Regression Model}

The remaining 25,508 cells are susceptible to lateral spreading. These cells vary widely in their likelihood of failure and they are distributed among only 12 of the 36 Dupré and Tinsley (1980) geologic units (Tables 2 and 5). Nine units were ranked by Tinsley (Table 5) as susceptible to spreading (ranks 1-4): undifferentiated alluvium (Qal), basin deposits $(\mathrm{Qb})$, beach sand (Qbs), channel fill (Qcf), dune sand (Qds), alluvial fan deposits (Qf), older flood plain (Qof), younger flood plain (Qyf), and levee and overbank deposits (Qyfa). Unit Qyfa is so thin, however, that it lies well above the ground-water table and thus is unlikely to liquefy-provided it does not overlie more susceptible deposits (in 1989, no lateral spreads were observed in unit Qyfa). Three of the 12 remaining units were judged by Tinsley as unlikely to spread: colluvium $\left(Q_{c}\right)$, Flandrian dunes (Qfd), and artificial fill (Qfl).

We defined relative susceptibility, $S_{R}$, as the probability, or chance (on a 0-1 scale), that a 1-ha parcel lies in one of two geologic units known to be most likely to fail by lateral spreading in an earthquake. To estimate $S_{R}$ for the 25,508 susceptible cells in the study area (Table 3) we used the probit option in the SHAZAM software, installed on the Sun SPARC workstation, to calculate

$$
\begin{aligned}
Z_{\mathrm{UNIT}}=B_{0} & +B_{1} \text { ASD }+B_{2} \text { LDIS } \\
& +B_{3} \text { MIDAGE }+B_{4} \text { LSLOPE }
\end{aligned}
$$

where $Z$ is an index number, determined by the dependent variable UNIT. UNIT has two states, 1 and 0 . UNIT $=1$ for the two sedimentary units that are judged most likely to liquefy and spread ( $n=3089$ cells; the 50 cells in unit Qyf? were omitted; Tables 4,5). These two deposits, younger flood plain (Qyf, $n=2572$ ) and channel fill ( $Q \mathrm{cf}, \mathrm{n}=567$ ), were ranked here as 1 (most susceptible; Tables 1 and 5); they are coded in the GIS as CLASS $=1$. The dependent variable UNIT $=0$ for the remaining ten units ( $n=22,419$ cells), coded as CLASS $=2$, 3,4 , or 0 (the latter including Qyf?, Qfd, and $Q c)$, which are less likely to fail than Qyf and Qcf (Table 5). ASD is average sand content (\%), LDIS is ln distance to nearest surface water $(m)$, MIDAGE is $\log _{10}$ midpoint of age (years BP), and LSLOPE is $\ln$ of slope angle (\%). Five values of $B$, the constant $B_{0}$ plus coefficients of regression $B_{1-4}$ for the four dependent variables described above, were estimated from values of the five variables (including UNIT) observed for or assigned to the 25,508 1-ha cells. The resulting equation after conversion of $Z$ values to $S_{R}$, susceptibility to lateral spreading on a 0.0 to 1.0 scale, is

$$
\begin{aligned}
S_{R}= & 4.8 \text { ASD }-0.56 \text { LDIS } \\
& -0.95 \text { MIDAGE }-0.28 \text { LSLOPE. }
\end{aligned}
$$

The regression computation required about 10 minutes and converged in six iterations. We suppressed $B_{0}$ in these calculations for three reasons. First, the constant has no explicitly physical meaning (Maddala, 1983), in this case with respect to lateral spreading. That is, $S_{R}$ would be zero without the four explanatory (earth-science) variables. Second, statistically, $B_{0}$ accounts for little added variance (about 5\%) in equation (1). Finally, inclusion of the constant reverses the sign of the coefficient of distance LDIS.

The regression coefficients of equation (1) indicate that sand content and age dominate the model. Slope is the weakest variable. The coefficients may be interpreted further, with due allowance for dispersion (Table 6), as follows: With each increase of, say, one percent in the likelihood of a 1-ha parcel in the Monterey Bay area being located in a geologic unit known to be highly susceptible to lateral spreading, and on the average, sand content is about five percent higher, mean distance to nearest open water is about two meters shorter, age of the deposit decreases by about nine years, and the angle of ground slope is about a percent less. Or, more to the point, each $5 \%$ increase in sand, 2-m decrease in distance, 9-year reduction in age, and $1 \%$ diminution in slope at a given cell increases, by roughly one percentage point, the probability that the parcel is located in one of the two geologic units most susceptible to lateral spreading (Qfy, Qcf). How actualistic is this model we have fit to the data? Coefficient values reveal that it is, like most such models, a compromise. The $5 \%$ increment of change in sand content, in particular, seems high. Because the regression does not include all variables we know to be relevant (e.g., residual shear stress), moreover, it is indicative 
Table 6

Performance of Probit Regression for Estimating Relative Susceptibility to Lateral Spreading $S_{R}$ from Four Variables

\begin{tabular}{|c|c|c|c|c|}
\hline $\begin{array}{l}\text { Variable } \\
\text { Name }\end{array}$ & Units & $\begin{array}{c}\text { Estimated } \\
\text { Coefficient, B }\end{array}$ & $\begin{array}{l}\text { Standard } \\
\text { Error }\end{array}$ & T-ratio* \\
\hline ASD & $\%$ & 4.8014 & 0.07572 & 63.41 \\
\hline LDIS & $\ln \mathrm{m}$ & -0.5588 & 0.01893 & -29.51 \\
\hline MIDAGE & $\log y r s$ & -0.9456 & 0.03580 & -26.42 \\
\hline LSLOPE & $\ln \%$ & -0.2798 & 0.01573 & -17.79 \\
\hline
\end{tabular}

*Significant values $>2.3(0.01$ level $)$

Prediction Success Table:\#

Number of cells actually observed in 0 or 1 state

$\mathbf{0}$-cell is in a "less

1--cell is in a "most susceptible" unit susceptible" unit

Number of cells predicted in 0 or 1 states by Model $\quad 1634$ (3\% false positives) 2796 (91\% correct)

\#Total observations: 25,508 1-ha cells Observations at 1: 3089 cells Observations at 0: 22,419 cells

Predicted at 1: 3430 cells Predicted at $0: 22,078$ cells

Diagnostic Statistics:

Cragg-Uhler R2:

F-test results:

0.76 (0-1 range: high $=$ good)

Durbin-Watson Statistic:

Autocorrelation coefficient:

26,926 (table value signif.: $\geq 2.95$ )

1.08 (table value signif.: $\geq 1.81$ )

0.46 (0-1 range: low = good) 



Figure 6. Frequency distributions of relative susceptibility, $S_{R}$, computed in the probit regression. A. all 25,508 map cells input to equation (1). B. the 363 cells that hosted lateral spreading in the 1989 Loma Prieta earthquake. 
only and we do not assert that equation (1) is a complete function for this particular hazard resulting from soil liquefaction.

\section{Statistical. Evaluation}

Equation (1) is a provisional model for mapping susceptibility to lateral-spread ground-failure in the Monterey Bay area. Its explanatory capacity may be judged from descriptive and diagnostic statistics (Table 6) as well as from the resulting map (Plate 1), mean $S_{R}$ values and other data for each geologic unit (Tables 5 and 7), and the frequency distribution of $S_{R}$ (Figure 6). The calculation is internally consistent and statistically significant. The signs of all four coefficients of multiple regression make sense geologically. In sum, and with due allowance for the log transformation of variables: susceptibility to lateral spreading in this area increases with high sand content, short distances to surface water, youth of the deposit, and low (approaching zero) slope angles. Table 6 reveals low standard errors and high t-ratios for the regression coefficients. Absolute values of $t$ lie between 18 (slope) and 63 (sand content), with $t>2.3$ being significant at the 0.01 level.

According to the Cragg-Uhler formulation for the multiple coefficient of determination $\mathbf{R}^{2}$, a diagnostic statistic of goodness-of-fit (i.e., "success") for probit regression (Gujarati, 1988, p. 175-177), our fourparameter model explains a satisfactory $76 \%$ of the variation in the observations (Table 6). However, we caution that much of this variance is intrinsic to the model by definition. (Such added variables as depth-to-ground water and median grain size might raise this percentage.) The F-test for overall significance of the regression by analysis of variance indicates a robust model; the calculated value of $F, 26,926$ (a high value reflecting the large sample), far exceeds the 2.95 table value. Finally, only moderate autocorrelation, an undesirable correlation between the explanatory variables, is present. This is revealed by moderate values (1.08) of both the Durbin-Watson statistic (table value $=1.81$ ) and the autocorrelation coefficient, rho $(0.46)$ desirable values of the two statistics are high and low, respectively (Table 6).

We were unable to detect in our results two other properties that can invalidate a multiple regression, or at least reduce its explanatory power: multicollinearity, a linear relation among some or all of the explanatory variables, and heteroscedasticity, inequality in the dispersion of their error terms (Gujarati, 1988, p. 283-352). Although conclusive tests are not available, the moderate $R^{2}$ and high tratios suggest that multicollinearity (commonly indicated by a high $R^{2}$ value and few significant coefficients) is unimportant in equation (1). Because heteroscedasticity commonly can be reduced by taking the logarithm of the variables, our log transformation of the three skewed variables to at least symmetric frequency distributions probably has minimized this property as well.

The regression statistics helped guide the heuristic course of modeling (Figure 3 ) that led to equation (1). In some two dozen such regressions we experimented with all 75,072 cells, untransformed variables, different combinations of fewer independent variables, obsolete (from 1:250,000-scale maps) terrain data for slope, unsmoothed values of elevation and slope, additional variables (e.g., median particle diameter, elevation above local base level), and different formulations of the dependent variable. Although several of these experiments produced minor improvements over the calculation yielding equation (1) and Plate 1 , including slightly better values of one or two diagnostic statistics, none of them gave the optimal combination of favorable outcomes described in this section.

In converging on a "best" solution, the most rationally defensible result that also achieved the greatest explanatory power, we monitored a combination of three criteria: logical signs for all regression coefficients [only attained in equation (1)], a high $R^{2}$ (which improved from 0.47 to 0.76 over the course of the experiment), and high $t$-ratios (well above the significance thresholds). Similarly, the autocorrelation coefficient rho fell from 0.75 to 0.46. The F-statistic was not diagnostic: given the large sample size, all regressions were 
significant. Not every hope was realized. We were unable to extract the correct coefficient sign for LELEV under any experimental conditions-too many less susceptible units (e.g., Qyfa, Qof) and highly susceptible units (e.g., Qyf) lie at similarly low elevations (Table 4). Nor could we obtain meaningful and consistent statistics from regressions using all 75,072 cells in the study area-too many susceptible (lowland flood plain) and nonsusceptible (upland hills) cells lie equally close to streams or have a similarly high sand content (Table 4).

\section{Geologic Evaluation and Interpretation}

Success of the model may also be judged by inspection, from the distribution of $S_{R}$ values among the various geologic units and from patterns on the resulting 1:62,500-scale color map of susceptibility for all 75,072 1-ha cells. For the 25,508 cells input to the regression calculation, the mean $S_{R}$ is 0.31 with a standard deviation of 0.37 -neither figure is representative of the frequency distribution. Figure 6 shows the highly skewed and bimodal distribution of these $S_{R}$ values; equation (1) tends to predict that susceptible sites in the Monterey Bay area are either very likely or unlikely to fail by lateral spreading in a large earthquake. According to equation (1) nearly half the 25,508 nonzero cells are essentially unsusceptible whereas about $12 \%$ are highly susceptible. Tables 3 and 5 confirm that this bimodality is distributed systematically by geologic unit. The highly susceptible units $Q y f$ and $Q_{c f}$ have mean $S_{R}$ values of 0.98 and 0.95 , whereas means of the less susceptible units Qof, $\mathrm{Qb}$, and Qyfa are only $0.02,0.28$, and 0.46 .

Plate 1 shows the close spatial association of high $S_{R}$ values with geologic map units previously classified as most susceptible (Tables 3 and 5) and with the locales that failed by lateral spreading in 1989 . Low $S_{R}$ values are associated with the least susceptible units. In Plate 1 the 0.0-1.0 range of $S_{R}$ values is divided into four even intervals plus a fifth category, $S_{R}>0.98$, which emphasizes the most highly susceptible cells identified by equation (1). The latter (red) pixels are concentrated in stream valleys, notably the two flanked by wide flood plains of late Holocene fluvial deposits (specifically Qyf), the Pajaro and Salinas Rivers. High $S_{R}$ values also cluster along the late Holocene beaches ( $Q b s$ ) and dunes ( $Q d s$ ) bordering Monterey Bay. $S_{R}$ values are high in such locales as Moss Landing, which was severely damaged in 1989. Large areas of older fluvial sediments (e.g., Qb and Qof), which characterize Elkhorn Slough and the former courses of the Salinas River, are characterized by systematically lower $S_{R}$ values.

Susceptibility values ranging from low to high, probably reflecting the variable width of the small flood plains, occur discontinuously along narrow stream valleys throughout the older Quaternary uplands.

Plate 1 is inconsistent in minor respects. The map contains some "noise"-clusters of aligned pixels, notably along quadrangle boundaries, and scattered single pixels that reflect systematic inaccuracies in the DEM and atypical combinations of the four input variables (compare, Table 7). A few locales that failed by lateral spreading in 1989 do not have high $S_{R}$ values, for example, the beach access road located on fill near Paul's Island, north of Elkhorn Slough. However, the thin $\mathrm{Qb}$ unit there overlies more susceptible sediments deposited when the Pajaro River occupied a different course, and it is the latter materials that failed in 1989. This concealment of liquefiable deposits by a veneer of sediments less likely to mobilize is common in all locales susceptible to lateral spreading (Ishihara and others, 1993); it poses a serious problem for GISbased approaches, as well as for insufficiently analytic geologic maps that present only visible map units at the expense of the third (vertical) dimension.

Probit regression generates dichotomous estimates of "success" in predicting susceptibility (Table 6). The classification by equation (1) of "less safe" versus "more safe" cells within the 25,508 non-zero $S_{R}$ values carries implications for mapping the hazard of lateral spreading. First, the model correctly identifies most areas of high susceptibility. Comparison of predicted low-susceptibility cells with all cells located in the nine geologic units of lower susceptibility reveals only 634 (3\%) false positives out of 22,419 total. That is, 
Table 7

Four-fold Signatures of Lateral-spread Susceptibility for 12 Geologic Map Units in the Monterey Bay area

\begin{tabular}{|c|c|c|c|c|c|c|c|}
\hline \multirow{3}{*}{$\begin{array}{l}\text { Map } \\
\text { Unit }\end{array}$} & \multirow{2}{*}{\multicolumn{2}{|c|}{$\begin{array}{l}\text { Susceptibility } \\
\text { Computed by } \\
\text { Regression, } S_{R}\end{array}$}} & \multirow{3}{*}{$\begin{array}{l}\text { Failed } \\
\text { Cells } \\
\text { as \% } \\
\text { of all } \\
\text { Cells }\end{array}$} & \multicolumn{4}{|c|}{ Mean Values of Descriptive Characteristics } \\
\hline & & & & \multirow{2}{*}{$\begin{array}{c}\text { Average } \\
\text { Age }^{*} \\
\text { (yrs BP) }\end{array}$} & \multirow{2}{*}{$\begin{array}{l}\text { Sand } \\
\text { Content* } \\
(\%)\end{array}$} & \multirow{2}{*}{$\begin{array}{c}\text { Distance } \\
\text { to Water } \\
\text { (m) }\end{array}$} & \multirow{2}{*}{$\begin{array}{r}\text { Ground } \\
\text { Slope } \\
(\%)\end{array}$} \\
\hline & Mean & $C_{v} \#$ & & & & & \\
\hline Qbs & 1.00 & 0.001 & 0.013 & 10 & 0.99 & 4 & 2.2 \\
\hline Qyf & 0.98 & 0.032 & 0.082 & 250 & 0.95 & 110 & 1.2 \\
\hline Qcf & 0.95 & 0.094 & 0.046 & 2500 & 0.88 & 133 & 0.6 \\
\hline Qds & 0.94 & 0.071 & 0.065 & 2500 & 0.98 & 80 & 1.6 \\
\hline Qfl & 0.59 & 0.426 & 0.018 & 50 & 0.50 & 207 & 1.4 \\
\hline Qal & 0.50 & 0.553 & - & 5000 & 0.63 & 115 & 3.1 \\
\hline Qyfa & 0.46 & 0.459 & 0.015 & 250 & 0.50 & 296 & 1.0 \\
\hline $\mathrm{Qb}$ & 0.28 & 0.949 & 0.004 & 5000 & 0.38 & 197 & 1.1 \\
\hline Qf & 0.20 & 0.980 & -- & 2500 & 0.50 & 227 & 2.4 \\
\hline Qfd & 0.20 & 0.869 & - & 7500 & 0.95 & 184 & 3.6 \\
\hline Qof & 0.02 & 3.000 & 0.006 & 2750 & 0.25 & 364 & 0.8 \\
\hline $\mathrm{Q}_{c}$ & 0.01 & 2.636 & -- & 2500 & 0.13 & 262 & 4.2 \\
\hline
\end{tabular}

* computed from maximum and minimum values (Table 2)

\# coefficient of variation, or relative dispersion (std. dev./ mean) 
only $3 \%$ of the cells for which no lateral spreading was observed in 1989 were erroneously classified by the model as "highly susceptible". Similarly, of the $\mathbf{3 0 8 9}$ cells observed to lie within the potentially "least safe" units Qyf and Qcf (Table 5), 293 (9\%) failed to be so identified by equation (1). The latter result may be interpreted in two ways: either the model failed to identify nearly a tenth of the "most dangerous" cells, or those 293 cells are rather less likely to liquefy and fail than others in the same geologic unit. According to the latter alternative, which we favor, the two most susceptible units Qyf and Qcf are not uniformly so, but vary in hazard, depending on such local factors as distance to the nearest stream and compositional variations in the sediment (compare, Tokimatsu and others, 1991). Data on distance to the water-table and the composition or distribution of point-bar deposits or other highly susceptible facies would perhaps aid in verifying this distinction.

The explanatory capability of equation (1) may be judged further by the values of $S_{R}$ it assigned to the 363 cells that actually hosted lateral spreading in the Loma Prieta earthquake (Table 5, Figure 6). These values range from 0.0 to 1.0 , with a mean of 0.80 and a standard deviation of 0.35 . We ran a chisquared test to determine formally whether $S_{R}$ of the 363 failed cells might be distributed randomly among $S_{R}$ for all cells (mean $=0.31 \pm$ $0.37)$ used in equation (1). Results of the test $\left(\chi^{2}\right.$ $=1154$ ) reject this hypothesis decisively at the 0.001 level (table $\chi^{2}$ value $=53$ ) confirming the rather obvious judgment by inspection that the 363 failed cells are preferentially located in areas of high $S_{R}$. The distribution of $S_{R}$ for the failed cells is bimodal, almost to the point of being dichotomous. Figure 6 shows that $70 \%$ (255) of the 363 cells have $S_{R}$ values exceeding $0.90, S_{R}$ is close to zero for $10 \%$ (37) of the cells, and the remaining $20 \%$ are distributed more or less evenly between zero and 0.90 . The lowscoring cells demonstrate a weakness of equation (1). However, the 37 zero-scoring cells all adjoin those that score $>0.90$ and only portions of the former cells, typically small corners, liquefied and spread in 1989. Most of these zero-scoring cells are located almost entirely in such low-susceptibility units as Qof (Plate 1,
Tables 5 and 7). A unit cell smaller than 1 ha would eliminate much of this problem.

The values of $S_{R}$ computed by probit regression offer us a new way to rank the 12 Holocene units by relative susceptibility to lateral spreading. Mean $S_{R}$ ranges from 1.00 (beach sand, $Q b s$ ) down to 0.01 (colluvium, Qc) (Table 5) and varies. with some regularity. The 12 averages are not randomly distributed, but cluster into four distinct groups that occupy only $29 \%$ of the $0.0-1.0 S_{R}$ range (Table 7). The most susceptible units (Qbs, Qyf, Qcf, and Qds) correspond largely to the red and orange cells mapped in Plate 1; the next highest-scoring group (Qfl, Qal, and Qyfa) accounts for much of the yellow in Plate 1; the third group $(Q b, Q f$, and Qfd) is largely green in Plate 1; and the least susceptible units, Qof and Qc, are mostly blue cells on the map. All three units with the highest percentages of failed cells in 1989 (Qyf, Qds, and Qcf) are in the first of these discrete groups of mean $S_{R}$ values, two of the three nexthighest percentages are in group two, and one of the two lowest percentages is in each of the last two groups in Table 7.

Mean $S_{R}$ values for geologic units vary widely, but systematically, in dispersion. The spread of $S_{R}$ values about their averages, measured by the standard deviation (Table 5), is best compared across the 12 map units using a measure of relative dispersion, the coefficient of variation, $C_{v}$ (std. dev./ mean). Values of $C_{v}$ range widely, from 0.001 (beach sand) to 3.0 (older flood plain), but the statistic correlates remarkably with mean $S_{R}$ (Table 7 ). Relative dispersion, which indicates stability of the averages, worsens (increases) with diminishing susceptibility $S_{R}$. The correlation is not a function of sample size. This distribution of $S_{R}$ dispersions suggests that the results of the regression are most reliable for the geologic map units most susceptible to lateral spreading.

Ordinal ranking of the 12 Holocene map units by mean susceptibility $S_{R}$ calculated in the regression model (Table 5 ) is comparable overall to the susceptibility rankings from field interpretation, frequency of lateral spreads in the 1989 Loma Prieta earthquake, and mean values of the four input variables (Table 8 ). 


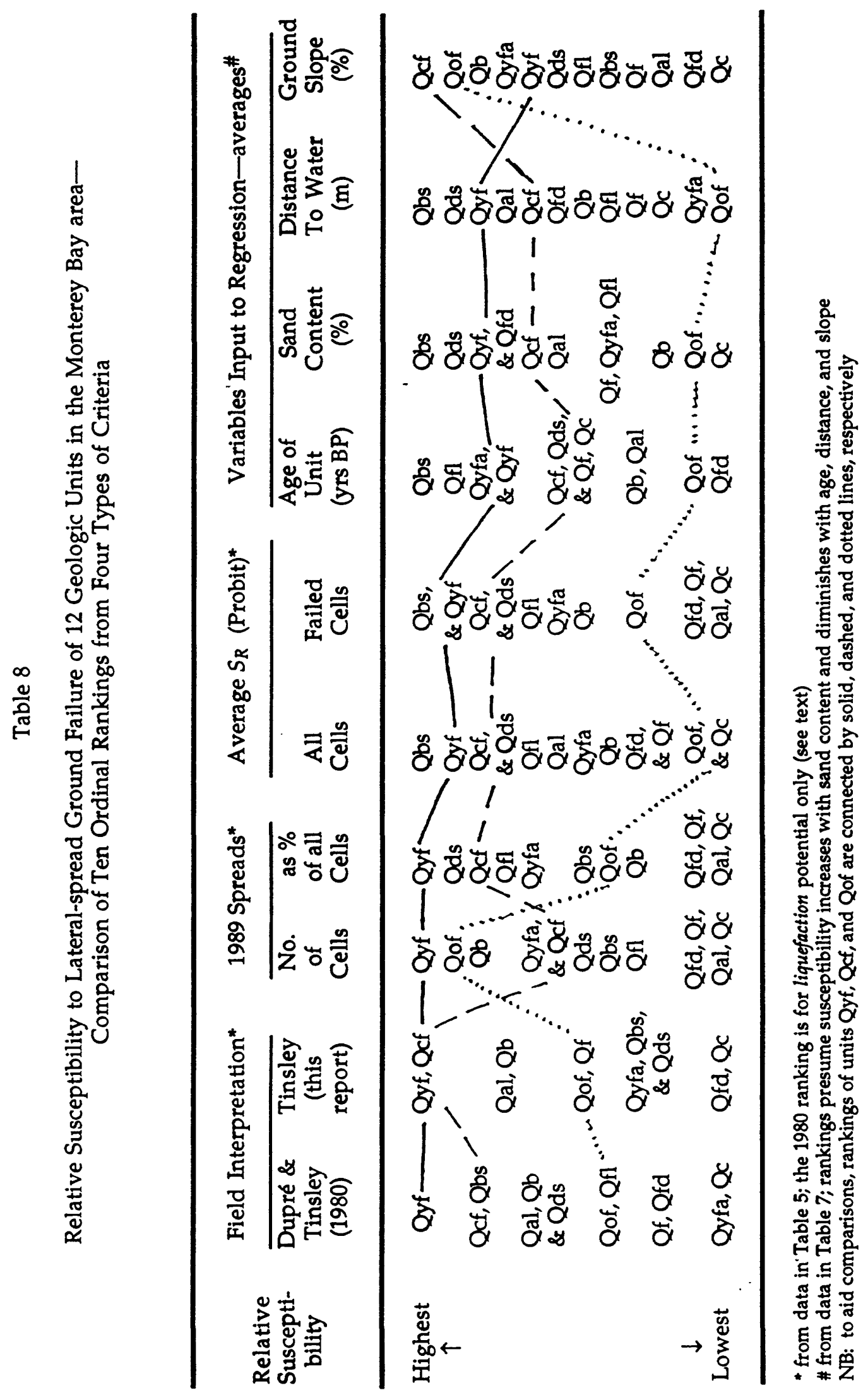




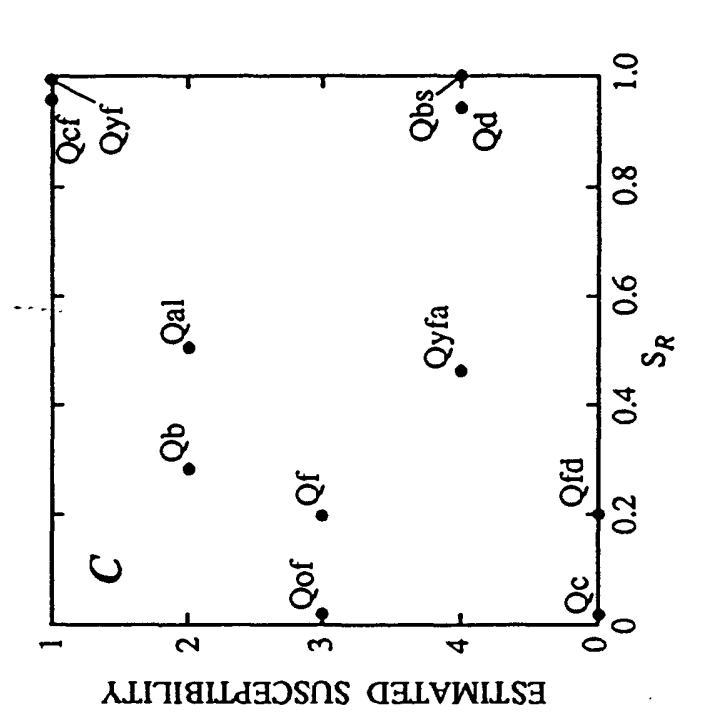

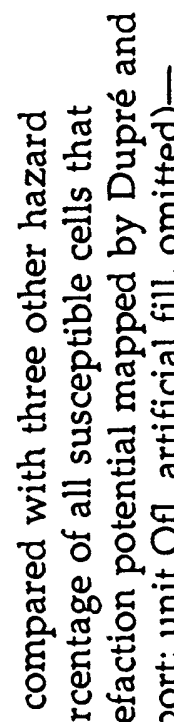

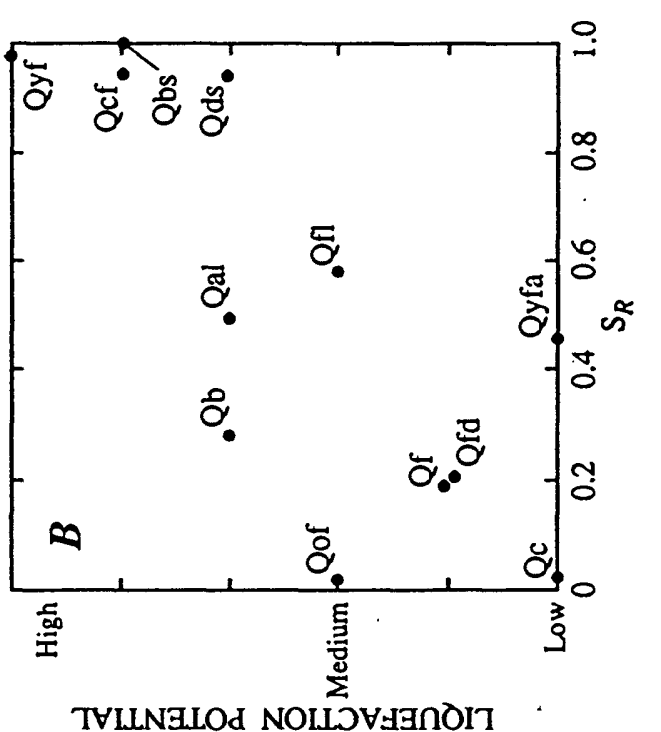

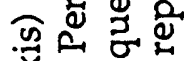

远当

『ี $\therefore$ 至

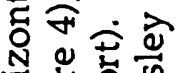

Nㅡㄴ 홍



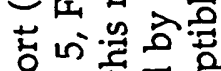

으웡

过

要

蛋焉

등ㅎㅎ돈잉

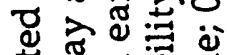

元

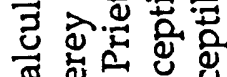

ชึ ญ्य

बे है है

की

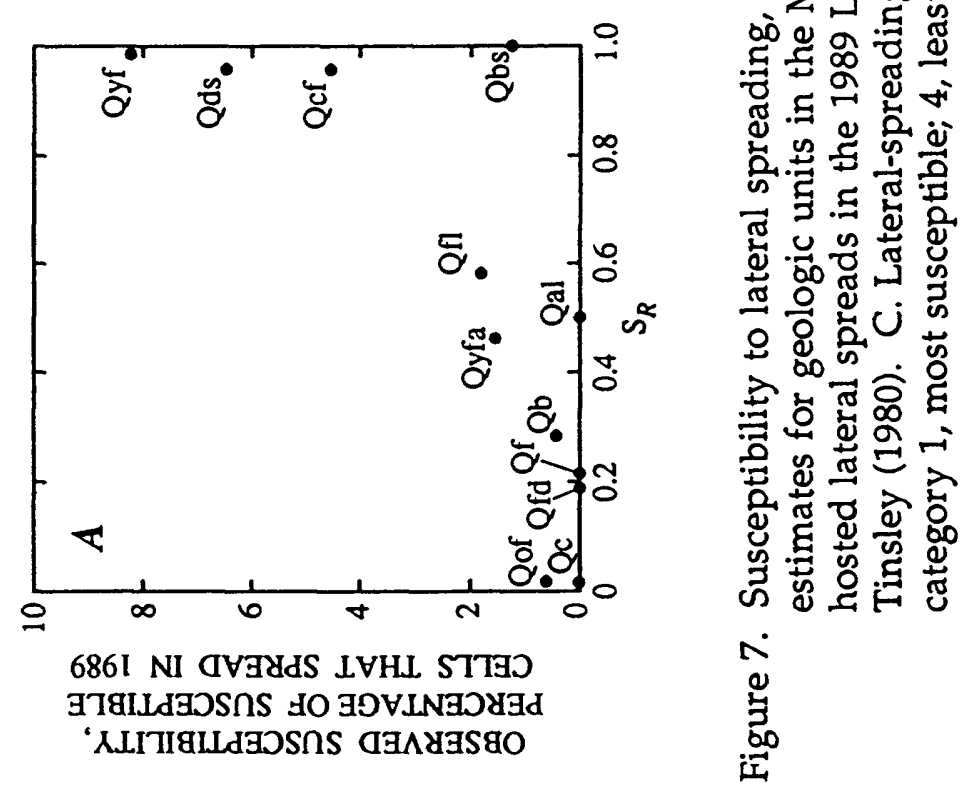


Because some map units occupy the same rank in an array, the arrays cannot be compared exactly. All ten arrays differ somewhat, although in no case is a geologic unit first in one ranking and last in another.

Both arrays by $S_{R}$ tend to rank units $Q y f$ and Qcf high, consistent with field study and the prevalence of 1989 spreads; unit Qcf largely parallels the Qyf trend across Table 8. No ranking by any one of the four input variables predicts Qyf as the most susceptible unit, however-it is their combination in equation (1) that has done so. The consistently high position of Qbs - obviously reflecting its extreme youth, very high sand content, and adjacency to the ocean-is an anomaly; it does not accord with observation of 1989 lateral spreads and is the most conspicuous failure of our model. Unit Qof occupies uniformly low ranks save for the number of 1989 spreads and ground slope. Mean $S_{R}$ values agree somewhat more with the Dupré and Tinsley (1980) ranking than with Tinsley's (Table 5, Figure 7 B,C), principally because of the change in ranking units Qbs and Qds, but the dispersion is considerable in both cases. With the conspicuous exception of beach sand ( $\mathrm{Qbs}$ ), average $S_{R}$ corresponds well with the observed frequency of lateral spreads (Figure 7A). The latter relation is strongly curvilinear, however, possibly because the dichotomous dependent variable in equation (1) could not be cast in logarithmic form. Finally, the raw count of failed cells (Table 5), when compared with $S_{R}$, is a poor predictor of susceptibility to lateral spreading in this area.

Contributions of the four input measures to the regression calculation are varied and complex (Tables 7 and 8 ). We ranked the 12 map units used in the model by the mean values of age, sand content, distance to water, and ground slope (Table 8). The four rankings correspond roughly with each other and with $S_{R}$ rankings by all cells and by failed cells, but reveal many differences in detail. These differences emphasize the need to use multiple characteristics in modeling the spatial domain of such physical processes as lateral spreading. The contrasts in rankings also highlight the anomalous beach sand unit (Qbs), which hosted fewer 1989 failures than predicted by Dupré and Tinsley (1980) or our $S_{R}$ model (Table 7). Only the ranking by ground slope seems to correctly reflect the modest percentage of failed cells in unit Qbs. (However, many of the failed Qof cells adjoin highly susceptible Qfy and Qcf cells; Plate 1.) Ground slope also is the best predictor of zero lateral spreading (units Qfd, Qf, Qal, and Qc). Further analysis of the four variables, which lies beyond the scope of this report, requires a principal-component transformation of the data (Pike, 1980).

We conclude that the susceptibility model, equation (1), may be unduly conservative in many places throughout the study area. Although most of the 3631 -ha cells that failed in 1989 are located in areas of high $S_{R}$ in Plate 1 , the converse is not true. The vast majority of cells $\geq 0.98 S_{R}$ did not fail by lateral spreading, or for that matter by any other consequence of soil liquefaction, in either the 1906 or 1989 earthquakes. In 1989, for example, little or no spreading was observed along Corralitos Creek, upper reaches of the Pajaro and Salinas rivers, and in Green Valley. Similarly, although few cells containing beach and dune materials failed in 1989, the computed $S_{R}$ values are uniformly high (Table 5). We ascribe the few failures in these many high- $S_{R}$ cells to the lack of sufficient water in the deposits at the time of the Loma Prieta event. We believe that accurate data on depth to ground water, the most critical of the generalized map variables missing from our model, and perhaps finer-scale slope data would have lowered the $S_{R}$ values for many such cells.

\section{DISCUSSION}

We have successfully modeled and mapped relative susceptibility to lateralspread ground failure for a small test area in central California, based empirically on two earthquakes' effects on the Holocene deposits of two coastal rivers and an eight-km-long strip of coastline. Although this sample is scarcely the remainder of coastal California, to say nothing of inland California or other states and countries, we believe we have made a good start at an overall approach to mapping the consequences of soil liquefaction statistically 
from generalized cartographic information and the judgment of experts. The specific technique developed here for lateral spreading should also apply to ground settlement and the eruption of sand boils. The degree to which the method may be transferred to mapping other hazards or successfully exported to other geologic settings remain to be determined.

This experiment in mapping natural hazard numerically has several implications. Here we briefly address portability of the model, the concept of susceptibility signatures, some limitations in using the map (Plate 1), data quality and availability, the changing research culture, and future requirements for earth-science map information.

Our overall approach and, with caution (Oreskes and others, 1994), even the specific model may be portable. If equation (1) is unique to the Monterey Bay area, it will not work elsewhere. Under favorable circumstances, however, all four variables and (less likely) the regression coefficients of equation (1) might apply to other parts of coastal California and possibly even to non-coastal areas of similarly susceptible (and mapped) geology and known or potential seismicity. A suitable candidate for a test of the model in an inland environment is the Santa Clara Valley, where the task of assessing lateral spreading by our method is complicated by a contrasting geologic setting (Youd and others, 1973; Power and others, 1992). This area is important because ground failure consequent to soil liquefaction could exacerbate the already serious problem of contaminants in the ground water (Olivieri and others, 1985; Helley, 1990). The overall-probabilisticmapping approach developed here using multiple regression, moreover, should apply to other types of earthquake-induced ground and slope failure (seismic shaking and landslides) as well as to nonseismic hazards (rainfallinduced landslides, wildfire, and flood) that lie beyond the scope of this investigation.

Susceptibility to lateral spreading at any locale in the study area can be estimated, if only in general terms, from a signature - the combination of diagnostic characteristics measured at each site (Pike, 1988). Averaged values of the four independent variables in the regression model, for each geologic unit, constitute a rudimentary fingerprint of lateralspread susceptibility for 1-ha cells in the Monterey Bay area. Table 7 gives crude fourfold signatures for the 12 Holocene map units. For example, a randomly chosen 1-ha cell in the highly susceptible younger flood plain (unit Qyf) can be expected, on the average, to contain materials that were deposited roughly 250 years ago, are about $95 \%$ sand, lie some $110 \mathrm{~m}$ from the nearest free face or open water, and slope at roughly $1.2 \%$. In contrast to unit $Q y f$, the deposits underlying a cell in the much less susceptible older flood plain (Qof) can be expected, on the average, to be at least 10 times older, contain a fourth the sand, lie over three times as far from the nearest free face, and have a ground surface about a third less steep. The order of slope means is reversed from that of the model (unit Qof also ranks unduly high under Ground Slope in Table 8). However, slope is the weakest of the four input variables and accuracy of the source DEM's is suspect.

The significance of these signatures (Table 7) lies in the potential for using site characteristics to suggest the geologic unit and infer its related susceptibility to lateral spreading, and to do so in areas other than Monterey Bay. For example, should field study of a coastal site in comparable Holocene materials elsewhere in California disclose an age of about 500 yrs BP, a composition of about $40 \%$ sand, a distance some $200 \mathrm{~m}$ to the nearest free face, and a ground slope of about one percent, then the sediments might be inferred to be alluvial basin deposits (e.g., unit $Q b$ )-with a $S_{R}$ of perhaps 0.30 and thus a low to moderate susceptibility to lateral spreading. Because dispersion about the means (not provided here) is very broad-the $C_{v}$ for $S_{R}$ alone (Table 7) ranges from a good 0.03 (Qyf) to a poor 3.0 (Qof)-and the raw data themselves are quite generalized, these small sets of values are far less diagnostic than, say, the geometric signatures computed for types of landslideprone terrain in Marin County, California (Pike, 1988). However, the means in Table 7 indicate the typical physical characteristics (and thus susceptibility to lateral spreading) that in combination are most likely to be encountered in any 1-ha cell of each geologic map unit in this area. More accurate observations and added variables (e.g., 
engineering measures and depth to ground water) would increase the diagnostic capabilities of these primitive signatures.

We urge the following caveats on potential users of Plate 1. It is suited for broadscale evaluation and planning only. Although the map's $100-m$ resolution may convey an impression of great accuracy and precision when compared with more generalized hazard maps, the data from which Plate 1 was computed are themselves coarse, incomplete, and contain various errors (e.g., slope). Thus the $S_{R}$ values, too, are subject to error. Not all of the relevant variables are reflected in Plate 1 , and the calculation did not incorporate the influence of shaking characteristics (e.g., direction)which vary from earthquake to earthquake and may be important in very large events. In particular, we caution against using Plate 1 to evaluate the lateral-spreading susceptibility of specific sites for possible building and other types of development. In all such circumstances, appropriately-licensed geologists or engineers should be engaged to evaluate the site in detail using such conventional field techniques of geotechnical analysis as soil-penetration tests (e.g., Seed and others, 1983; Kavazanjian and others, 1985). Finally, although earthquakeinduced ground settlement can be expected to occur in much the same areas mapped as highly susceptible in Plate 1 , the map should not be used to assess secondary hazards of soil liquefaction other than lateral spreading.

Our work raises issues in the quality and availability of earth-science map information. Most important, many Quaternary deposits subject to seismically induced ground-failure are mapped in insufficient detail and with scant attention to such physical properties as sand content and particle sorting. The minimal age distinctions needed for such models as ours are good stratigraphic estimates of the Pleistocene, early Holocene, and late Holocene. Depth to ground water-critical to modeling lateralspread susceptibility-is not well mapped in most areas of liquefiable soils, much less distinguished by wet and dry seasons or with respect to normal and drought cycles. Next, digital terrain data produced to current USGS standards are not well suited to modeling the likelihood of lateral spreading because of their inherently low signal-to-noise ratio in smooth topography. Present 1:24,000-scale DEM's are not accurate enough to alone distinguish terrain more likely to liquefy $\left(\mathrm{ca} \leq 3^{\circ}\right.$ ) from steeper low-relief terrain-at least in geologic settings where such a distinction is germane. This suggests that slope may be inappropriate for equation (1) and should be excluded from future models. Finally, the inadvertent concealment of susceptible materials by such thin overlying deposits as units $\mathrm{Qb}$ and $\mathrm{Qyfa}$ (Plate 1) remains an unresolved problem in mapping Quaternary geology for application to soil liquefaction and other hazards. Resolution of this issue may require a review of both mapping philosophy and norms for the graphical presentation of information on geologic maps.

Our approach to mapping a natural hazard, adapted from econometrics and implemented by a GIS, departs from routine practice in applied geology in that the work was unusually cross-disciplinary. We doubt that any individual field geologist, geotechnical engineer, economist, geographer, physical scientist, computer professional, statistician, or exploratory data-analyst alone would have created equation (1) and Plate 1. Also, transfer of our results into the realm of public policy and financial decisionmaking is certain to entail cooperation with government officials and other professionals who may have little or no background in earth-science (Berz, 1994). We conclude that the ability to be flexible and work outside one's own specialty are now as important as skills in GIS and other advanced technology. Future success in applications of the breadth and complexity evidenced here will require closer interaction among diverse areas of expertise than has been customary in the largely basic-science environment of traditional geologic research (e.g., Molnia, 1994).

This work exemplifies only one of many ways that earth-science mapping over broad areas contributes to the mitigation of natural hazards (Varnes, 1974; Robinson and Spieker, 1978; Brabb, 1987; Borcherdt and others, 1991; Mark, 1992; Bernknopf and others, 1993; King and Kiremidjian, 1994). Such applications of synoptic data are information-intensive. They cannot succeed without a digital archive of systematic observations, compiled and supported at the national level, to insure both 
the consistency and the geographic coverage required to meet unanticipated needs (Turner and Youd, 1987; National Research Council, 1993; Matsuoka and others, 1993). Datacollection ad-hoc in response to local emergencies created by specific natural disasters, while seemingly cheaper than maintaining a national archive, is in the end uneconomical and inefficient.

Finally, it would be a mistake to infer from our work that computers and digital databanks can replace experienced professionals. Although geologic-, hydrologic-, and topographic-map data and GIS technology allcontributed importantly to the model developed here, the model could not have been created without the judgments of field geologists expert in mapping Quaternary deposits (e.g., Dupré and Tinsley, 1980). Young fluvial and deltaic sediments pose the greatest risk of lateral spreading in an urban setting subject to seismic activity. Thus, detailed geologic mapping of late-Holocene deposits in the relevant metropolitan areas (e.g., Helley, 1990; Holzer, 1994), is perhaps the most urgent information-gathering challenge faced by the earth-science community in mitigating this particular hazard to the public welfare.

\section{RECOMMENDATIONS FOR FURTHER WORK}

Much work remains, both to improve and apply our results for the Monterey Bay area and to extend the approach developed here to other locales similarly at risk. Perhaps six main areas for further research into lateral-spread ground failure can be identified.

Our multiple-regression model is subject to revision in its assumptions, input data, and statistical treatment. For example, $S_{R}$ is so severely skewed and bimodal (Figure 6) that its distribution in Plate 1 is equally so. We can not reduce this asymmetry by the usual expedient of log-transforming the dependent variable in equation (1)-which is dichotomous. (Because of the way this model is formulated, the better the fit the more dichotomous the result.) Another issue is ground slope, both its general applicability and its accuracy. Slope may be an appropriate, if not a very powerful, predictor of lateral spreading only in the Monterey study area. Aside from the problem of DEM quality, we do believe that slopes calculated on the original 30-m DEM grid would be more accurate (and markedly steeper) than the 1-ha-gridded values input to equation (1)-and thus exclude from the probability model more than 36 of the 357 cells on beach sand and three out of the 324 cells on dune sand (compare Tables 4 and 5). Data resolution poses some problems. The 1-ha grid is so coarse that a cell containing a map unit much narrower than $100 \mathrm{~m}$ (e.g. beach or channel deposits) will be contaminated by the characteristics of adjacent units. Next, added variables will strengthen the procedure. We reiterate the need for some estimate of depthto-ground water in subsequent models. As a general observation, finally, we would like to reduce further the amount of earth-science expertise required to apply this regional (in contradistinction to geotechnical) approach. One way to do this might be to improve the direct regression of observed lateral-spread damage on the various physical factors.

Second, more work is needed to validate the generalized approach to mapping such a local, site-specific, hazard. Although our model of lateral-spread susceptibility is intended for broad-scale evaluation only, it should still be compared against the detailed geotechnical measures customarily used for microzonation of liquefaction-derived hazards. The results of standard penetration tests (SPT), if available in enough of the geologic map units and their various sedimentary facies, would provide satisfactory criteria for such an evaluation and perhaps a calibration of equation (1) in terms more accepted in conventional engineering-geotechnical practice.

Third, this work has addressed lateral spreading, only one of several types of liquefaction-induced ground deformation. Other modes of failure in the study area are important geologic hazards; these include the settlement of structures owing to bearingcapacity failures, the floatation of such buried objects as swimming pools and storage tanks, and differential subsidence of the ground. Accordingly, we recommend that mapped observations on sand boils and settlements be 
incorporated in future models to broaden the geographical area of interest and the scope of study to include other liquefaction-related sources of permanent ground failure.

Fourth, the next logical steps in applying our results in the Monterey Bay area are to estimate the opportunity and probability of lateral spreading from the frequency of occurrence of strong ground motions. There are various ways of doing this (e.g., Power and others, 1991 and 1992). We made a first attempt at calculating actual probability of lateral spreading in a specific earthquake (Loma Prieta), using a model of peak ground acceleration (Joyner and Boore, 1981; Boore and others, 1993). The regression model differed from equation (1), but the resulting map (not shown) resembled Plate 1 (Bernknopf, Mark, and others, 1993) $\longrightarrow$ suggesting that site characteristics rather than the spatial distribution of ground motion are the main determinants of lateral spreading in this area. A different approach would incorporate ground motion directly into equation (1) (compare, Mark, 1992). It is also clear that alternative parameters of seismic shaking (e.g., Arias intensity: Kayen, 1993; Wilson, 1993) may be superior to peak acceleration and warrant some experimentation. Further uncertainties in mapping various aspects of lateral spreading are addressed by Youd (1991).

Fifth, we have not yet obtained satisfactory data sets on demographics and property valuation with which to combine our susceptibility results to map actual dollars-atrisk in the study area (e.g., Bernknopf and others, 1988; Bernknopf, Brookshire, and others, 1993). It is these projected monetary estimates that will have the greatest impact on the formulation of public policy for financial decisionmaking (Berz, 1994). The applications of such follow-on work in statistical estimation of lateral spreading and its economic and social implications, both in the Monterey Bay area and elsewhere, are many. They include hazard recognition and mapping; risk assessment and mitigation; land-use zoning at municipal, regional, and state levels; routing of lifelines; siting of emergency facilities and other public infrastructure; operations planning for emergency response; preservation of civil order; and the fine-tuning of loss estimation and insurance underwriting (Brabb, 1987; Shah and others, 1991; Bernknopf and Soller, 1994; King and Kiremidjian, 1994).

Finally, the value of this work will be limited if the approach is not portable. While provisionally successful, our first experiments applying equation (1) to six $7.5^{\prime}$ quadrangles in the Santa Clara Valley have raised several issues that are still under study. Because the Quaternary geologic history and depositional environments differ from those in the Monterey Bay area, the mapped units and thus the statistical models are not directly comparable. These contrasts are most evident in the systematically lower sand content of the Santa Clara Valley deposits, at least in the samples available to us thus far. Also, the overall mix of geologic formations is different, and there are fewer units from which to model susceptibility. However, the 1906 record of lateral spreading and ground fissuring that is needed to calibrate such a model is available for the Santa Clara Valley. Additionally, the many incidences of non-liquefaction ground deformation (e.g., pipe breaks) recorded in the 1989 Loma Prieta earthquake offer a new data set that may help in formulating and testing a statistical model for the effects of ground liquefaction away from the Monterey Bay area. (Although natural alluvial soils in the Santa Clara Valley did not liquefy in 1989, they would fail in a more severe event-as they did in 1906; Seed and others, 1991.) We also plan to experiment with a regression model that uses damaged sites as the dependent variable and includes a categorical estimate of susceptibility among the independent variables.

\section{SUMMARY AND CONCLUSIONS}

We assessed the susceptibility to one secondary type of seismically induced groundfailure associated with soil liquefactionlateral spreading-for 36 geologic units mapped in the Monterey Bay area of central California. Susceptibility is defined operationally, based on the judgment of experts, as presence/absence of sedimentary deposits most likely to liquefy. We designed a two-stage model to rapidly create probabilistic maps for land-use and financial decisionmaking in public policy. 
Geologic, hydrologic, and topographic data in digital-map form were used first as threshold criteria and then combined in a multipleregression calculation. This quantitative approach yields continuous values of hazard estimates that are easier to apply in some types of subsequent work (e.g., economic modeling) than categorical qualities (e.g. "low", "high"). Our threshold/ stochastic method of mapping hazard susceptibility was implemented in a geographic information system (GIS) with a spatial resolution of $100 \mathrm{~m}$.

The first step, which identified areas unlikely to liquefy in a major earthquake, eliminated all but 12 geologic units. The 49,564 1-ha parcels in bedrock or unconsolidated sediments too old $(>10,000$ yrs BP) or (in this specific geologic setting) too steep $\left(>3^{\circ}\right)$ to spread laterally were assigned susceptibility values of zero.

We then estimated the relative susceptibility $\left(S_{R}\right)$ to lateral spreading for the remaining 25,508 cells from a multiple-linear (probit) regression. $S_{R}$, the dependent variable, is the chance (on a 0-1 scale) that a cell lies in one of the two geologic units known to be most likely to liquefy and fail by lateral spreading. The four independent variables calculated for each cell are sand content $(\%)$ and log age (yrs BP) of 11 geologic units plus artificial fill (data obtained from field mapping), In horizontal distance to nearest free face or surface water $(m$, from hydrologic DLG's), and In terrain slope (\%, from DEM's). The resulting values of $S_{R}$, mapped in the Arc/Info GIS for the 25,508 cells in six 7.5' quadrangles, are independent of any particular earthquake. The regression equation,

$$
\begin{array}{r}
S_{R}=4.8 \% \text { sand }-0.56 \ln \text { distance } \\
-0.95 \log \text { age }-0.28 \ln \text { slope, }
\end{array}
$$

shows that susceptibility to lateral spreading increases with youth and sand content of the deposit, low surface slope, and proximity to a stream. Diagnostic statistics show that the regression is internally consistent and significant at the $1 \%$ level and explains $76 \%$ of the variance. Owing to its method of formulation, the model is almost dichotomous; most $S_{R}$ values are high or low (the average value, $0.31 \pm 0.37$, is not meaningful).
Additional information, including estimates of depth-to-ground water and digital terrain data of higher accuracy, would improve the model.

The resulting map makes sense geologically. Spatial groupings of high $S_{R}$ values coincide with the most susceptible geologic unit (Qyf)-composed largely of late Holocene flood-plain (channel and point bar) deposits. The 363 cells that include groundfailure by lateral spreading in the 1989 Loma Prieta earthquake are characterized by high $S_{R}$ values (mean $=0.80 \pm 0.35$ ). The 12 units are arrayed, by diminishing susceptibility $S_{R}$, in four discrete groups: beach, younger flood plain, channel fill, and young dunes; artificial fill, undifferentiated alluvium, and thin levee and overbank deposits; basin deposits, alluvial fans, and older dunes; and older flood plain and colluvium. This ranking agrees generally with other evaluations of relative susceptibility. The regression model is conservative; not only do most high- $S_{R}$ cells contain no failures, but the hazard of lateral spreading to beach sand is overestimated. The geologic units are not uniformly susceptible: the sites most at risk within each unit lie closest to active streams and the seacoast.

Successful calibration of this initial experiment in the probabilistic mapping of lateral-spreading susceptibility carries several implications:

1. With due caution, some version of our model may be transferable from Monterey to coastal locations elsewhere in California and perhaps to other areas of similarly susceptible (and mapped) Quaternary geology and known or potential seismicity.

2. The stochastic approach to mapping developed here should apply to other types of earthquake-induced ground and slope failure as well as to nonseismic natural hazards.

3. Geologic, topographic, and hydrologic information in digital-map form all contribute essential ingredients to the multivariate model.

4. The GIS-based model developed here relies critically on the judgment of a geologist expert in the specific hazard-a large-scale map of Quaternary geology is the most important component in our model of lateralspread susceptibility. 
5. The strong cross-disciplinary teamwork required by our approach to hazard mapping may presage shifting trends in the earthscience research environment, especially where supported by public funds.

We conclude further that the spatial variation of a geologic hazard, assessed numerically by digital information from earthscience maps, leads directly to maps of important derivatives. The results reached here can be combined with regional data on seismic shaking to model the probability of lateral spreading in a specific earthquake and, in turn, those results can be combined with information on demographics and property valuation to estimate and map potential losses in actual dollars-at-risk. This probabilistic approach has applications in financial decisionmaking for public policy. They include hazard mapping, risk assessment and mitigation, planning and zoning at all levels of government, emergency response, maintenance of public safety, and insurance underwriting.

\section{ACKNOWLEDGMENTS}

GIS work by Geoffrey Phelps was critical to this report; we accept with reluctance his decision to decline coauthorship. David Boore, William Dupré, Todd Fitzgibbon, Edward Helley, William Joyner, Kathryn Nimz, David Soller, and Carl Wentworth helped in various ways. The manuscript was reviewed and improved by Robert Kayen and Stephen Obermeier, whose constructive comments have been incorporated throughout, commonly verbatim. We appreciate the cooperation of these USGS colleagues.

\section{REFERENCES}

Bennett, M.J., 1990, Ground deformation and liquefaction of soil in the Marina District, in Effects of the Loma Prieta earthquake on the Marina District, San Francisco, California: U.S. Geological Survey, open-file report 90-253, Chapter D, 36 p.

Bernknopf, R.L., Brookshire, D.S., Soller, D.R., McKee, M.J., Sutter, J.F., Matti, J.C., and Campbell, R.H., 1993, Societal value of geologic maps: U.S. Geological Survey, Circular 1111, 53 p.
Bernknopf, R.L., Campbell, R.H., Brookshire, D.S., and Shapiro, C.D., 1988, A probabilistic approach to landslide hazard mapping in Cincinnati, Ohio, with applications for economic valuation: Bull. Assoc. Engineering Geologists, v. 25, no. 1, p. 3956.

Bernknopf, R.L., Mark, R.K., Phelps, Geoffrey, Pike, R.J., and Tinsley, J.C., 1993, Hazard of earthquake-induced liquefaction modeled from earth-science data in a geographic information system (GIS) [abs.]: Eos Transactions of the American Geophysical Union, v. 74, no. 43 (Supplement), p. 433.

Bernknopf, R.L., and Soller, D.R., 1994, Earthquake hazard mitigation: using science for safety decisions: U.S. Geological Survey, Open-file Report 94-172, 40 p.

Berz, Gerhard, 1994, The insurance industry and the IDNDR (International Decade for Natural Disaster Reduction) - common interests and tasks: Natural Hazards, v. 9, no. 3, p. 323-332.

Boore, D.M., Joyner, W.B., and Fumal, T.E., 1993, Estimation of response spectra and peak accelerations from western North American earthquakes-an interim report: U.S. Geological Survey Open-File Report 93-509, 72 p.

Borcherdt, R.D., Janssen, A., Fumal, T., and Gibbs, J., 1991, Methodology for predictive GIS mapping of special study zones for strong ground shaking in the San Francisco Bay region, CA: International Conference on Seismic Zonation, 4th, August 2629, 1991, Stanford, CA, Proceedings, v. III, p. 545552.

Brabb, E.E., 1987, Analyzing and portraying geologic and cartographic information for land-use planning, emergency response, and decisionmaking in San Mateo County, California, in

ASPRS/ACSM Conference, GIS '87-San Francisco, October 26-30, Proceedings: v. 1, p. 362-374.

Burmaster, D.E., and Lehr, J.H., 1991, It's time to make risk assessment a science: Ground Water Monitoring Review, v. 11, no. 3, p. 5-15.

Burrough, P.A., 1986, Principles of geographical information systems for land resources assessment: Oxford, Clarendon Press, 193 p. [corrected printing, 1987]

Chang, T.-S., Chang, K.-P., Chung, W.-Y., and Johnston, A.C., 1992, Earthquake hazard evaluation in the Central New Madrid seismic zone: Memphis, TN, Memphis State University, Center for Earthquake Research and Information, USCS Contract No. 1408-0001-G2000, Report, 96 p.

Cowan, D.J., 1988, GIS versus CAD versus DBMS, what are the differences?: Photogrammetric Engineering and Remote Sensing, v. 54, no. 11, p. 1551-1555. 
Davis, J.C., 1986, Statistics and data analysis in geology (2nd ed.): New York, Wiley, 646 p.

Dillon, W.R., and Goldstein, Matthew, 1984, Multivariate analysis, methods and applications: New York, Wiley, 587 p.

Draper, N.R., and Smith, H., 1981, Applied regression analysis (2nd ed.): New York, Wiley, 709 p.

Dupré, W.R., and Tinsley, J.C. III, 1980, Maps showing geology and liquefaction potential of northern Monterey and southern Santa Cruz Counties, California: U.S. Geological Survey, Miscellaneous Field Studies map MF-119, 2 sheets, scale $1: 62,500$.

Dupré, W.R. and Tinsley, J.C., in-press, Evaluation of liquefaction mapping hazard in the Monterey Bay area, central California, in Holzer, T.H., ed., Liquefaction, Chapter B of Strong ground motion and ground failure, V.2 of the Loma Prieta earthquake of October 17, 1989: U.S. Geological Survey Professional Paper 1551-B.

Elton, D.J., and Hadj-Hamou, Tarik, 1990, Liquefaction potential map for Charleston, South Carolina: American Society of Civil Engineers, Journal of Geotechnical Engineering, v. 116, no. 2, p. 244265.

Emmi, P.C., and Horton, C.A., 1991, An assessment of casualty risk due to earthquake ground shaking, Salt Lake City, Utah: Annual ESRI user conference, 11 th, Redlands, CA, Proceedings, v. 2, p. 309-320.

Environmental Systems Research Institute (ESRI), Inc. 1992, Understanding GIS, the ARC/INFO method (rev. 6.0): Redlands, CA, ESRI, variously paged.

Fuller, M.L., 1912, The New Madrid earthquake: U.S. Geological Survey Bulletin 494, 119 p.

Gauch, H.G., Jr., 1993, Prediction, parsimony and noise: American Scientist, v. 81, no. 5, p. 468-478.

Gujarati, D.N., 1988, Basic Econometrics (2nd ed.): New York, McGraw-Hill, 705 p.

Hansen, W.R., 1965, Effects of the earthquake of March 27, 1964, at Anchorage, Alaska: U.S. Geological Survey Professional Paper 542-A, 68 p.

Helley, E.J., 1990, Quaternary geology and pollution problems-an example from the San Francisco Bay area, California, in Doe, B.R., ed., Proceedings of a U.S. Geological Survey workshop on environmental geochemistry, U.S. Geological Survey Circular 1033, p. 87-96.

Hoel, P.G., 1962, Introduction to mathematical statistics (3rd ed.): New York, Wiley, 428 p.
Holzer, T.L., 1994, Predicting earthquake effectslearning from Northridge and Loma Prieta: Science, v. 265, p. 1182-1183.

Hwang, H.H.M., and Lee, C.S., 1991, Probabilistic evaluation of liquefaction potential: National Center for Earthquake Engineering Research, SUNY Buffalo, Tech. Report NCEER-91-0025, paged by section.

Ishihara, Kenji, Acacio, Alex A., and Towhata, lkuo, 1993, Liquefaction-induced ground damage in Dagupan in the July 16, 1990 Luzon earthquake: Soils and Foundations, v. 33, no. 1, p. 133-154.

Ishihara, Kenji, Haeri, S.M., Moinfar, A.A., Towhata, lkuo, and Tsujino, Shuichi, 1992, Geotechnical aspects of the June 20,1990 Manjil earthquake in Iran: Soils and Foundations, v. 32, no. 3, p. 61-78.

Ishihara, Kenji, Okusa, Shigeyasu, Oyagi, Norio, and lschuk, Anatoliy, 1990, Liquefaction-induced flow slide in the collapsible loess deposit in Soviet Tajik: Soils and Foundations, v. 30, no. 4, p. 73-89.

Ishihara, Kenji, and Yasuda, S., 1991, Microzonation for liquefaction potential during earthquakes in Japan: International Conference on Seismic Zonation, 4th, August 26-29, 1991, Stanford, CA, Proceedings, v. I, p. 703-724.

Joyner, W.B., and Boore, D.M., 1981, Peak horizontal acceleration and velocity from strong-motion records including records from the 1979 Imperial Valley, California, earthquake: Bulletin of the Seismological Society of America, v. 71, p. 20112038.

Juang, C.H., and Elton, D.J., 1991, Use of fuzzy sets for liquefaction susceptibility zonation: International Conference on Seismic Zonation, 4th, August 2629, 1991, Stanford, CA, Proceedings, v. II, p. 629 - 636 .

Kavazanjian, Edward, Roth, R.A., and Echezuria, Heriberto, 1985, Liquefaction potential mapping for San Francisco: Journal of Geotechnical Engineering, v. 111, no. 1, p. 54-76.

Kayen, R.E., 1993, Accelerogram-energy approach for prediction of earthquake-induced ground liquefaction: Univ. California, Berkeley, unpublished Ph.D. dissertation, 289 p.

King, S.A., and Kiremidjian, A.S., 1994, Regional seismic hazard and risk analysis through geographic information systems: Stanford University, Department of Civil Engineering, Blume Earthquake Engineering Center, Report No. $111,168 \mathrm{p}$.

Lawson, A.C., and seven others, 1908, The California earthquake of April 18, 1906--Report of the State Earthquake Investigation Comission: Carnegie Institute of Washington Publication 87, v. 1 and atlas, $451 \mathrm{p}$. 
Maddala, G.S., 1983, Limited-dependent and qualitative variables in econometrics: Cambridge University Press, $401 \mathrm{p}$.

Mark, R.K., 1992, Map of debris-flow probability, San Mateo County, California: U.S. Geological Survey, Miscellaneous lnvestigations Series, Map I-1257-M, scale 1:62,500, 2 sheets.

Martin, J.R., II, and Clough, G.W., 1990, Implications from a geotechnical investigation of liquefaction phenomena associated with seismic events in the Charleston, SC area: Blacksburg, VA, Virginia Polytechnic Institute and State University, Department of Civil Engineering, USGS Contract No. 14-08-001-G-1348, Final Report, 414 p.

Matsuoka, Masashi, Midorikawa, Saburoh, and Wakamatsu, Kazue, 1993, Liquefaction potential mapping for large area using the digital national land information: Jour. Struct. Constr. Engineering, AIJ, no. 452, Oct., p. 39-45.

McHarg, I.L., 1969, Design with nature: Garden City, NY, Natural History Press, 198 p.

Molnia, B.F., 1994, Washington Report-Geology by Committee: GSA Today, v. 4, no. 11, p. 270-271.

National Research Council, 1985, Liquefaction of Soils during Earthquakes: U.S. National Academy of Sciences, Washington, D.C., 240 p.

National Research Council, 1993, Solid-Earth Sciences and Society: U.S. National Academy of Sciences, Washington, D.C., 350 p.

Obermeier, S.F., 1989, The New Madrid earthquakesAn engineering-geologic interpretation of relict liquefaction features: U.S. Geological Survey Professional Paper 1336-B, 114 p.

Obermeier, S.F., Jacobson, R.B., Smoot, J.P., Weems, R.E., Gohn, G.S., Monroe, J.E., and Powars, D.S., 1990 , Earthquake-induced liquefaction features in the coastal setting of South Carolina and in the fluvial setting of the New Madrid seismic zone: U.S. Geological Survey, Professional Paper 1504, $44 \mathrm{p}$.

Olivieri, A.W., and eight others, 1985, Assessment of contamination from leaks of hazardous materials in the Santa Clara ground water basin, 205J Report: San Francisco Regional Water Quality Control Board, SEEHRL (University of California, Berkeley), and Santa Clara Valley Water District, $160 \mathrm{p}$.

Omernik, J.M., 1978, Ecoregions of the conterminous United States: Annals of the Association of American Geographers, v. 77, no. 1, p. 118-125.

Oreskes, Naomi, Shrader-Frechette, Kristin, and Belitz, Kenneth, 1994, Verification, validation, and confirmation of numerical models in the earth sciences: Science, v. 263, no. 5147, p. 641-646.
Pike, R.J., 1980, Geometric interpretation of lunar craters: U.S. Geological Survey Professional Paper 1046-C, 77 p.

Pike, R.J., 1988, The geometric signature-quantifying landslide-terrain types from digital elevation models: Mathematical Geology, v. 20, no. 5, p. 491511.

Power, M.S., Perman, R.C., Wesling, J.R., Youngs, R.R., and Shimamoto, M.K., 1991, Assessment of liquefaction potential in the San Jose, California, urban area: International Conference on Seismic Zonation, 4th, August 26-29, 1991, Stanford, CA, Proceedings, v. II, p. 677-684.

Power, M.S., Wesling, J.R., Perman, R.C., Youngs, R.R., and LiSilvestro, L.A., 1992, Evaluation of liquefaction potential in San Jose, California: San Francisco, Geomatrix Consultants, U.S. Geological Survey Award Grant No. 14-08-0001G1359, Final Technical Report, 65 p.

Robinson, G.D., and Spieker, A.M., eds., 1978, Nature to be commanded-Earth-science maps applied to land and water management: U.S. Geological Survey Professional Paper 950, 95 p.

Ross, Malcolm, 1990, Hazards associated with fibrous minerals, in Doe, B.R., ed., Proceedings of a U.S. Geological Survey workshop on environmental geochemistry, U.S. Geological Survey Circular 1033, p. 175-176.

Seed, R.B., Dickenson, S.E., and Idriss, I.M., 1991, Principal geotechnical aspects of the 1989 Loma Prieta earthquake: Soils and Foundations, v. 31, no. 1, p. 1-26.

Seed, H.B., and Idriss, I.M., 1982, Ground motions and soil liquefaction during earthquakes: Earthquake Engineering Research Institute (EERI), Monograph series, No. 5, Berkeley, CA, 134 p.

Seed, H.B., Idriss, I.M., and Arango, Ignacio, 1983, Evaluation of liquefaction potential using field performance data: American Society of Civil Engineers Journal of Geotechnical Engineering, v. 109 , no. 3, p. 458-482.

Shah, Hemant, Boyle, Richard, and Dong, Weimin, 1991, Geographic information systems and artificial intelligence - an application for seismic zonation: International Conference on Seismic Zonation, 4th, August 26-29, 1991, Stanford, CA, Proceedings, v. I, p. 487-517.

Soller, D.R., Stettner, W.R., Lanfear, K.J., and Aitken, D.S., 1990, A user's manual for a method of map scanning and digital editing for thematic map production and data-base construction: U.S. Geological Survey Circular 1054, 38 p.

Stewart, J.P., Bray, J.D., Seed, R.B., and Sitar, Nicholas, eds., 1994, Preliminary report on the principal geotechnical aspects of the January 17, 1994 Northridge earthquake: University of California 
at Berkeley, College of Engineering, Earthquake Engineering Research Center, Report No. UCB/EERC-94/08, 245 p.

Tinsley, J.C., and Dupré, W.R., 1992, Liquefaction hazard mapping, depositional facies, and lateral spreading ground failure in the Monterey Bay area, central California, in Hamada, M., and O'Rourke, T.D., eds., Japan-U.S. Conference on earthquake resistant design of lifeline facilities - . and countermeasures for soil liquefaction, 4th, Honolulu, HI, May 27-29, 1992, Proceedings, v. 1, p. 71-86.

Tinsley, J.C., Egan, J.A., Kayen, R.E., Bennett, M.J., and Holzer, T.L., in press, Maps and descriptions of liquefaction and associated effects - the Loma Prieta earthquake of October 17, 1989, in Holzer, T.L., ed., The Loma Prieta earthquake of October 17, 1989: U.S. Geological Survey Professional Paper 1551-B.

Tinsley, J.C. III, Youd, T.L., Perkins, D.M., and Chen, A.T.F., 1985, Evaluating liquefaction potential, in Ziony, J.1., ed., Evaluating earthquake hazards in the Los Angeles region-an earth-science perspective: U.S. Geological Survey Professional Paper 1350, p. 263-315.

Tokimatsu, K., Kojima, H., Yamashita, J., Fukumoto, S., and Midorikawa, S., 1991, Liquefaction hazard mapping in Dagupan City during the Philippine earthquake of July 16, 1990: International Conference on Seismic Zonation, 4th, August 2629, 1991, Stanford, CA, Proceedings, v. II, p. 613620.

Turner, W.G., and Youd, T.L., 1987, National map of liquefaction hazard--mapping and synthesis of geologic hazards and establishment of information systems: Provo, Utah, Brigham Young University, Department of Civil Engineering, U.S. Geological Survey Grant No. 14-08-0001-G1187, Final Report, 72 p.

Varnes, D.J., 1974, The logic of geological maps, with reference to their interpretation and use for engineering purposes: U.S. Geological Survey Professional Paper 837, 48 p.

Wentworth, C.K., Borcherdt, R.D., Fitzgibbon, T.T. and Showalter, P.K., 1991, Application of GIS technology to seismic zonation in the San Francisco Bay region, California: International Conference on Seismic Zonation, 4th, August 2629, 1991, Stanford, CA, Proceedings, v. III, p. 537544.

Wesnousky, S.G. and Leffler, L.M., 1992, The repeat time of the 1811 and 1812 New Madrid earthquakes-A geological perspective: Bulletin of the Seismological Society of America, v. 82, no. 4, p. $1756-1785$.

White, K.J., and Bui, L.T., 1988, Basic Econometrics, a Computer Handbook Using SHAZAM: New York, McGraw Hill, 245 p.
White, K.J., Wong, S.D., Whistler, Diana, and Haun, S.A., 1990, SHAZAM econometrics computer program; user's reference manual, version 6.2: McGraw-Hill, New York, 352 p.

Wilson, R.C., 1993, Relation of Arias intensity to magnitude and distance in California: U.S. Geological Survey open-file report 93-556, 42 p.

Youd, T.L., 1973, Liquefaction, flow and associated ground failure, U.S. Geological Survey Circular $688,12 \mathrm{p}$.

Youd, T.L., 1991, Mapping of earthquake-induced liquefaction for seismic zonation: International Conference on Seismic Zonation, 4th, August 2629, 1991, Stanford, CA, Proceedings, v. 1, p. 111147.

Youd, T.L., and Hoose, S.N., 1977, Liquefaction susceptibility and geologic setting: World Conference on Earthquake Engineering, 6th, New Delhi, India, Proceedings, v. 6, p. 37-42.

Youd, T.L., and Hoose, S.N., 1978, Historic ground failures in northern California triggered by earthquakes: U.S. Geological Survey Professional Paper 993, 177 p.

Youd, T.L., and Perkins, D.M., 1978, Mapping liquefaction-induced ground failure potential: American Society of Civil Engineers, Journal of the Geotechnical Engineering Division, v. 104, no. GT4, p. 433-446.

Youd, T.L., and Perkins, D.M., 1987, Mapping of liquefaction severity index: American Society of Civil Engineers, Journal of Geotechnical Engineering, v. 113, no. 11, p. 1374-1392.

Youd, T.L., and Perkins, J.B., 1987, Map showing liquefaction susceptibility of San Mateo County, California: U.S. Geological Survey Miscellaneous Investigations Map I-1257-G, scale 1:62,500.

Youd, T.L., and Wieczorek, G.F., 1982, Liquefaction and secondary ground failure, in The Imperial Valley, California, earthquake of October 15, 1979: U.S. Geological Survey Professional Paper 1254 , p. $223-246$.

Youd, T.L., Nichols, D.R., Helley, E.J., and Lajoie, K.R., 1973, Liquefaction potential of unconsolidated sediments in the southern San Francisco Bay region, California: U.S. Geological Survey, openfile report no. 1924,23 p.

Youd, T.L., Tinsley, J.C. III, Perkins, D.M., King, E.J., and Preston, R.F., 1978, Liquefaction potential map of San Fernando Valley, California: International Conference on Microzonation for Safer Construction-Research and Applications, 2nd, San Francisco 1978, Proceedings, v. 1, p. 267278. 